\title{
C-Cells and their Associated Lesions and Conditions: A Pathologists Perspective
}

\author{
Zubair W. BALOCH, Virginia A. LIVOLSI \\ Department of Pathology \& Laboratory Medicine, University of Pennsylvania, Perelman School of Medicine, PHILADELPHIA, PA, USA
}

\begin{abstract}
This paper updates the histopathology and cytopathology of thyroid tumors and proliferations derived from the para-follicular or C cells. Beginning with an historical over view, including the recognition of medullary thyroid carcinoma as a distinct histologic entity, its relationship to the hormone, calcitonin, (which was discovered in the same decade) and to thyroid C cells, medullary carcinoma and its variants are reviewed. The molecular biology of the tumors and the associated mutations in the tumors (somatic mutations) are discussed. Additionally the genetic features (germline mutations) including familial clusters and associations with other endocrine and neuroendocrine lesions are reviewed. Screening for the tumor and its precursors is included with a review of the latest American Thyroid Association guidelines for treatment as well as timing and approach to surgery. Tabular data of specific germline mutations and their relationships to tumor virulence, and prognosis are illustrated. Precursor and early $\mathrm{C}$ cell lesions such as C-cell hyperplasia and micro-medullary carcinoma are discussed. Difficulties and controversies in the definition of C-cell proliferations which are neoplastic and those which are "reactive" are reviewed. The entity of medullary microcarcinoma or medullary microcarcinoma is illustrated and the distinction between $\mathrm{C}$ cell nodules and microcarcinoma is defined using the latest available criteria. Finally the latest approved chemotherapeutic agents and their results in metastatic medullary thyroid carcinoma are included.
\end{abstract}

Key Words: Medullary thyroid carcinoma, Thyroid cancer, RET, Genetics, Tyrosine kinase inhibitors

\section{INTRODUCTION}

The definition and description of medullary thyroid carcinoma is only about half a century old but the importance of this tumor in terms of its recognition for diagnosis, and its separation from follicular derived thyroid tumors has engendered a massive literature. Medullary carcinoma was one of the earliest human malignancies to be associated with a specific tumor marker, calcitonin, which became critically important molecule because it could be used diagnostically and prognostically in patients with this tumor.

The syndromes associated with medullary carcinoma including multiple endocrine neoplasia types IIA, IIB (or III) and familial medullary carcinoma which described early the knowledge in understanding of the tumor itself. The genetic implications were also recognized quickly and led to the development of readily available and reliable genetic testing in the clinical setting. Finding germline mutations in ret proto-oncogene allowed for early diagnosis and intervention before the development of the tumors or when they manifested at very early stage.

The recognition of precursor lesions such as neoplastic C-cell hyperplasia (both diffuse and nodular) and the earliest manifestation of the tumor, that is, micro-medullary

(Turk Patoloji Derg 2015, 31(Suppl):60-79)

Received : 03.06.2015 Accepted : 06.06.2015 carcinoma in prophylactic thyroidectomy has led to the recognition of these entities by histopathologists in thyroid resections and apparently sporadic cases of medullary carcinoma.

The wide variety of patterns which medullary carcinoma can assume, offers a challenge to histopathologists and even more diagnostic difficulty to the cytopathologists. The current authors have noted numerous examples in their consultative practice of thyroid aspiration biopsies of medullary carcinoma, which have been diagnosed as lesions of follicular origin, follicular neoplasms, or follicular lesions of uncertain significance (FLUS). It is likely that the relative rarity of medullary carcinoma of the thyroid complicates the evaluation of thyroid FNAs in the setting of increased frequency of sporadic thyroid nodules of follicular origin.

From the molecular pathology point of view, medullary carcinoma and its related lesions were the first thyroid neoplasms and pre-neoplasms to be extensively studied. This resulted in a) the recognition of genetically determined neoplasms and precursors, b), the testing of relatives of patients with apparent sporadic medullary carcinoma leading to the discovery of families with the disease, c) the development of screening tests leading to prophylactic thyroidectomy and d) analytical studies of numerous

Correspondence: Zubair W. BALOCH

Department of Pathology \& Laboratory Medicine, 6 Founders Pavilion, 3400 Spruce Street, University of Pennsylvania, Perelman School of Medicine, Philadelphia, PA. 19104, USA

E-mail: baloch@mail.med.upenn.edu Phone: +1 2156623209 
families with various germline mutations allowing for tabulated recommended timing (age) for surgical intervention in as yet unaffected relatives of patients with this tumor.

This review will focus on various aspects of medullary thyroid carcinoma and its precursor lesions predominantly from the cytopathology and histopathology view points; the known implications of molecular (genetic) testing in terms of prognosis will be discussed; the difficult area of frank C-cell hyperplasia as compared to borderline lesions will be also reviewed including a brief discussion of socalled reactive $\mathrm{C}$-cell hyperplasia.

\section{HISTORICAL PERSPECTIVE}

The hormone, calcitonin, was discovered and characterized in the early 1960s; the thyroid C cell had been described in many animal species by the end of the 19th and early 20th centuries. Nonidez reported the presence of argyrophilic cytoplasmic granules C-cells and also remarked on their para-follicular location; he also hypothesized that these cells may have endocrine function (1). The term "calcitonin" was first coined by Copp and Cheney in as a substance of parathyroid origin as it was responsible for lowering serum calcium levels (2). The thyroid origin of calcitonin was first confirmed by Hirsch in 1963 and Foster in $1964(3,4)$. The term "C-cells" was introduced by Pearse and later on with Bussolati demonstrated the presence of calcitonin in these cells by immunofluorescence. Interestingly, parallel to all these discoveries $(5,6)$ in the early 1960 s, pathologists were defining the morphology of the tumor now known as medullary thyroid carcinoma (MTC) $(7,8)$. In 1966, Williams proposed that MTC might be derived from the $\mathrm{C}$ cell and predicted that if the $\mathrm{C}$ cell was the source of calcitonin, the tumors might also produce this hormone (9). Meyer and Abdel-Bari in 1968 demonstrated calcitoninlike activity in extract derived from medullary thyroid;(10) this observation was later confirmed by Bussolati and colleagues by immunofluorescence techniques (11).

The $\mathrm{C}$ cells are derived embryologically from the neural crest and migrate into the thyroid along with the ultimobranchial body. Hence, these two elements may be closely associated in the adult thyroid; however, the ultimobranchial body itself does not show calcitonin immunoreactivity and should not be considered as hyperplastic $C$ cells $(12,13)$. In humans, $\mathrm{C}$ cells are found along the lateral aspects of the thyroid lobes in the upper two-thirds of the gland. The $\mathrm{C}$ cells comprise less than $0.1 \%$ of the thyroid mass in humans $(14,15)$. Wolfe and colleagues showed C-cell distribution in the thyroid by immunohistochemistry. The number of $\mathrm{C}$ cells in the thyroid differs according to age. They identified larger numbers of these cells in infants and children under the age of 6 than in adults. In children, groups of up to six cells can be seen, with as many as 100 cells noted in a low-power microscopic field. In adult glands no more than 10 cells should be found in a low-power field $(14,15)$.

Clusters of $\mathrm{C}$ cells in adults have been described in endocrinologically normal adults. O'Toole and colleagues examined thyroid glands from forensic autopsies and recognized a trend toward increased numbers of these cells in older individuals (over age 60); however, they noted large standard deviations (16). This remains a problem area for pathologists (17).

\section{MEDULLARY THYROID CARCINOMA}

Medullary thyroid carcinoma is rare and comprises fewer than $10 \%$ of all thyroid malignancies (18-20). This tumor is of great diagnostic importance because of its aggressiveness, its close association with multiple endocrine neoplasia syndromes MEN type 2A (MEN IIA or Sipple's syndrome); type 2B (MEN IIb, MEN III or mucosal neuroma syndrome) or familial non-MEN MTC (FMTC), and a relationship to C-cell hyperplasia as probable precursor lesion (20-22). While the majority of medullary carcinomas are sporadic, up to $25 \%$ are familial $(23,24)$.

In 1985, Masahide Takahashi transfected NIH 3T3 fibroblast cells with sonicated human lymphoma DNA segments, which resulted in transformation of these cells (25). Subsequent studies demonstrated that this new biologically active gene was generated by recombination of two separate normal DNA segments. The name "RET" means "REarranged during Transfection" represents the transforming gene product found in Takahashi's experiment (25). The proto-oncogene RET is composed of 21 exons located on chromosome 10 (10q11.1) and encodes for a transmembrane receptor tyrosine kinase for members of the glial cell line-derived neurotrophic factor family (GDNF) and associated ligands nurturing, artmemin, and persephin. RET is involved in a number of cellular signaling pathways during development regulating the survival, proliferation, differentiation, and migration of the enteric nervous system progenitor cells, as well as survival and regeneration of neural and kidney cells (26-28).

The genetic linkage analysis performed in 1987 by two separate investigators mapped the MEN2A locus to a region on chromosome $10(29,30)$. In 1990 increased expression of the RET gene was found in both familial and sporadic human MTC and pheochromocytomas by Santoro and colleagues (31). Based on mapping of the RET 
gene on chromosome 10 these investigators also suggested that this region of chromosome 10 might be involved in the proliferation and differentiation of neuroectodermal tissues (31). At present it is well known that virtually all patients with familial MTC have germline RET mutations, whereas up to $75 \%$ of patients with sporadic MTC have somatic RET mutations, a feature of clinical aggressiveness (23,32-35).

\section{CLINICAL PRESENTATION \& GENETICS}

The clinical features are similar in both sporadic and familial cases that are symptomatic (18,20,32,36). Medullary carcinoma can affect patients of any age; however, most affected individuals are adults with an average age of about 50 years $(18,19)$. In familial cases, though, children can be affected; also in these instances the age of diagnosis tends to be younger (mean age: about 20 years) (24). Although sporadic medullary carcinomas are seen more commonly in women, familial cases have an equal sex ratio, since an autosomal-dominant mode of inheritance is present (20,24,37-39).

Most patients with medullary carcinoma will present with a painless and firm thyroid nodule. In up to $50 \%$ of cases, obvious nodal metastases will be present at the time diagnosis. Distant metastases to lung, bone, or liver may also be noted initially in about $15 \%$ to $25 \%$ of cases $(40,41)$. When the tumor produces excess hormone other than calcitonin, the presenting symptoms may be related to that hormone hypersecretion (adrenocorticotropic hormone [ACTH], prostaglandin)(42-45).

In the familial forms there are associated endocrine or neuroendocrine lesions (Table I). To date over 100 mutations (single or multiple), duplications, insertions or deletions involving RET oncogene have been identified in patients with hereditary MTC. Mutations in RET in families with MEN-2A (95\% of families) and FMTC (85\% of families) have been seen in one of the five-cysteine codons in exon 10 and exon 11 (19,35,46-51).

Sipple syndrome (MEN type II or IIA) also known as "Classical MEN2A" consists of medullary thyroid cancer and C-cell hyperplasia, adrenal pheochromocytoma and adrenal medullary hyperplasia, and parathyroid hyperplasia $(52,53)$. Although most affected patients will have the complete syndrome, not every patient will manifest each of these lesions. Even in families with the complete syndrome, parathyroid lesions affect only $16-25 \%$ of patients. In MEN-2A RET-mutations usually occur in codons 609,618 , or 620 of exon 10 or codon 634 of exon $11(19,34,54,55)$. The latter is identified frequently $(>60 \%)$; and has been

Table I: Phenotypic/clinical characteristics of multiple endocrine neoplasia (MEN) type-2 variants

\begin{tabular}{|c|c|c|}
\hline Variant \& RET germline mutations & Phenotypic/clinical characteristics & Percentage of affected patients \\
\hline \multicolumn{3}{|l|}{$\begin{array}{c}\text { MEN 2A } \\
\text { exon 10: codons 609, 611, 618, } 620 \\
\text { exon 11: codon 634 }\end{array}$} \\
\hline & Medullary Thyroid Carcinoma & $95-100$ \\
\hline & Pheochromocytoma & 50 \\
\hline & $\begin{array}{c}\text { Parathyroid Hyperplasia-Primary } \\
\text { Hyperparathyroidism }\end{array}$ & $20-30$ \\
\hline & Hirschsprung's disease & $<1$ \\
\hline & Cutaeous Lichen Amylodosis & Codon $634(38)$ \\
\hline \multicolumn{3}{|l|}{$\begin{array}{c}\text { MEN 2B(>100 mutations) } \\
\text { Exon 10: } 609,611,618 \& 620\end{array}$} \\
\hline & Medullary Thyroid Carcinoma & 100 \\
\hline & Pheochromocytoma & 50 \\
\hline & Mucosal-intestinal ganglioneuromas & 100 \\
\hline & Marfanoid Habitus & 100 \\
\hline \multicolumn{3}{|l|}{$\begin{array}{c}\text { FMTC } \\
\text { exon 10: 611, exon 13: 768, } \\
\text { exon 16: } 912 \\
\end{array}$} \\
\hline & Medullary Thyroid Carcinoma & 100 \\
\hline
\end{tabular}


associated with the presence of pheochromocytoma and hyperparathyroidism and rarely cutaneous lichen amyloidosis (56-61). Patients with MEN2a and a unilateral pheochromocytoma usually develop contralateral adrenal lesion within 10-years. RET-germline mutations are present in $50 \%$ of patents with Hirschprung's Disease (HD); which can be seen in approximately $7 \%$ of patients with MEN2A. The HD usually manifests shortly after birth; it is important to exclude HD in older MEN2A patients presenting with colonic symptoms. It has been shown that a variety of phenotypic expressions in MEN-2A families can be seen with the same RET mutations $(57,59,62)$. Mutations in specific codons have been correlated with clinical behavior and symptomatology in some families $(59,61,63-65)$.

MEN type IIB consists of medullary thyroid carcinoma and C-cell hyperplasia, pheochromocytoma and adrenal medullary hyperplasia, mucosal neuromas, gastrointestinal ganglioneuromas, and musculoskeletal abnormalities $(33,60,66-70)$. These patients may have familial disease (over $50 \%$ do); some cases arise apparently as spontaneous mutations. A point mutation at codon M918T (exon 16) has been noted in $95 \%$ of cases with MEN-2B (71-73). The other rare mutations reported in MEN2B patients include genotype A883F (exon 15), double mutation V804M/Y806C at codon 804 (exon 14) and 806 in the same allele (72,7476). Mutations in codons 918 and 883 are associated with MTC presenting at younger age with high risk of mortality and disease-specific mortality $(72,77,78)$. Because MTC is generally considered a lethal tumor, it is recommended that first degree relatives of the affected family member should undergo genetic screen; a positive result should be followed be prophylactic total thyroidectomy $(24,79$ 82). Most endocrinologists and pediatric endocrinologists recommend total thyroidectomy before the age of six in children found to have "aggressive" RET mutations in their germline $(19,24,79,83)$. MEN IIB shows similarity to von Recklinghausen disease since in neurofibromatosis similar lesions are found in the gastrointestinal tract, and pheochromocytomas are common. Nerve growth factor has been identified in some medullary carcinomas of these patients; it has been postulated that this product of the tumor may be responsible for the neural lesions seen in patients with MEN type IIB (84). However, the neural lesions often precede the development of medullary cancer by many years.

Familial medullary thyroid carcinoma is characterized by the presence of a RET germline mutation in families with MTC, or in a patient with MTC without known family history of MTC. These both scenarios of MTC occurrence are unassociated with neither pheochromocytoma nor hyperparathyroidism $(20,24,85,86)$.
Sporadic medullary thyroid carcinomas can also demonstrate RET mutations; these are usually limited to the tumor cells and rarely in germline (indeed if found in the latter, the possibility of familial disease needs to be considered) (87). In sporadic MTC, somatic mutations have been seen in exon 16 of the RET (M918T) in 11-60\% of cases; this variability shows a strong correlation with tumor size. The M918T mutations in sporadic MTC are associated with aggressive clinical course and prognosis. The rare somatic mutations in sporadic MTC are seen in codon 618, $603,634,768,804,883$ and partial deletion of RET gene (77,87-93). It has been shown that $80 \%$ of sporadic MTC lacking somatic RET mutations have mutations in RAS oncogene (HRAS, KRAS, or rarely NRAS) (24,94-97).

The pathologist may contribute to the determination of familial rather than sporadic disease if, upon examining a medullary carcinoma of the thyroid, he or she notes multifocal or bilateral tumors and the presence of C-cell hyperplasia $(18,20,36)$.

\section{PATHOLOGY}

Medullary carcinoma is usually located in the area of highest C-cell concentration (i.e., the lateral upper two-thirds of the gland). In familial cases, multiple small nodules may be detected grossly, and rarely, lesions may be found in the isthmus. The tumors range in size from barely visible to several centimeters. Many medullary carcinomas are grossly circumscribed but some will show infiltrative borders. Gross necrosis and hemorrhage can also be seen $(18,20,22,36,98)$.

The typical medullary carcinoma may be microscopically circumscribed or more likely will be freely infiltrating into the surrounding thyroid. The pattern of growth is of tumor cells arranged in nests separated by varying amounts of stroma. The tumor nests are composed of round, oval, or spindle-shaped cells; there often is isolated cellular pleomorphism or even multinucleated cells. (Figure 1,2). The nuclei are uniform, demonstrate characteristic neuroendocrine stippled chromatin with low nuclear/ cytoplasmic ratio (Figure 3). Intranuclear cytoplasmic inclusions are commonly noted. Mitoses can be seen. The tumor stroma characteristically contains amyloid although this is not necessary for the diagnosis; about $25 \%$ of medullary carcinomas do not contain amyloid (Figure 4,5 ). The amyloid is most likely derived from procalcitonin and, indeed, immunohistochemical stains for calcitonin often stain the amyloid (Figure 6). Calcifications in areas of amyloid deposition are characteristically present. The tumors commonly invade lymphatics and veins $(18,36)$. 


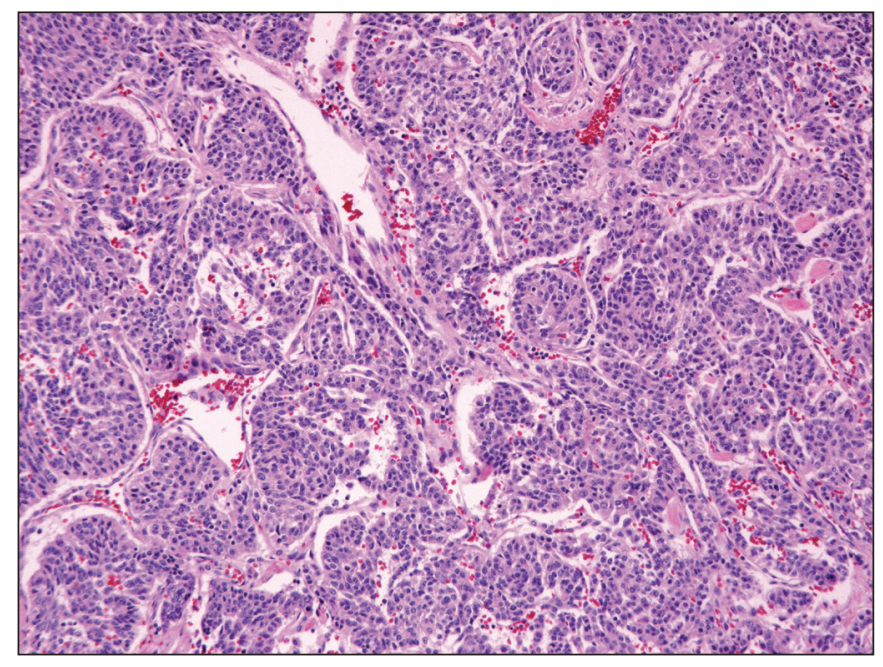

Figure 1: A case of medullary carcinoma demonstrating "nesting" growth pattern; commonly observed in neuroendocrine tumor. Notice lack of obvious amyloid in this case (H\&E, 10x).

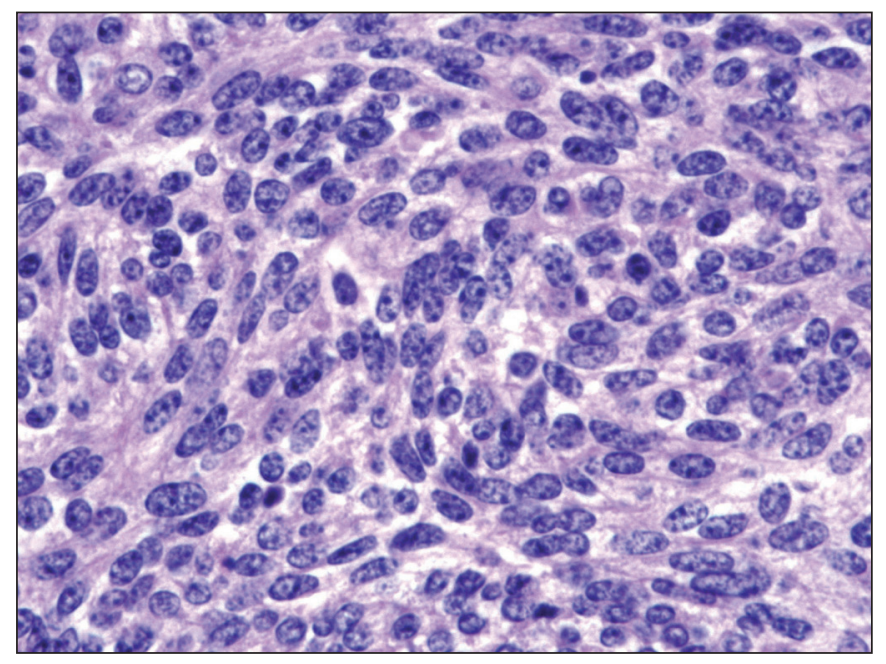

Figure 3: Spindle shaped cells in medullary carcinoma; notice the neuroendocrine type (AKA salt and pepper) nuclear chromatin (H\&E; 40x).

Several medullary carcinoma variants have been described. In the papillary variant, a papillary or pseudopapillary growth pattern is identified. The pseudopapillary variant is more common and probably results from fixation artifact $(99,100)$. The true papillary variant is extremely rare and needs to be differentiated from typical papillary thyroid carcinoma; nuclear morphology is the most important distinguishing feature (101-103). The follicular variant (Figure 7) is characterized by the presence of follicles, glands, or tubules $(99,104)$. Care must be rendered to determine that the follicular structures are not just entrapped normal thyroid within the lesion $(99,105)$. Some medullary carcinomas are grossly and microscopically

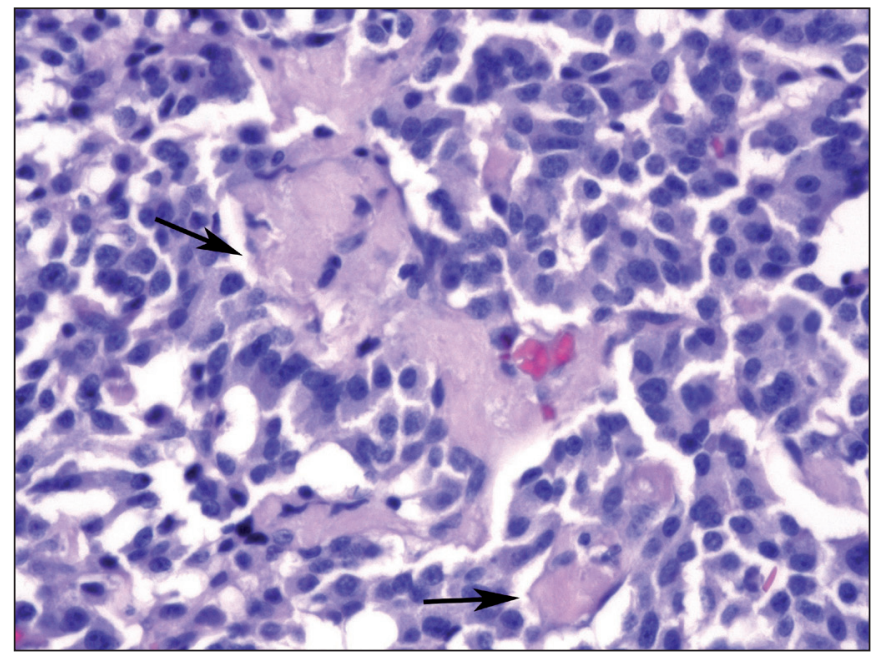

Figure 2: Plasmacytoid tumor cells in medullary carcinoma associated with amyloid appearing as acellular eosinophilic deposits (arrows) (H\&E; 20x).

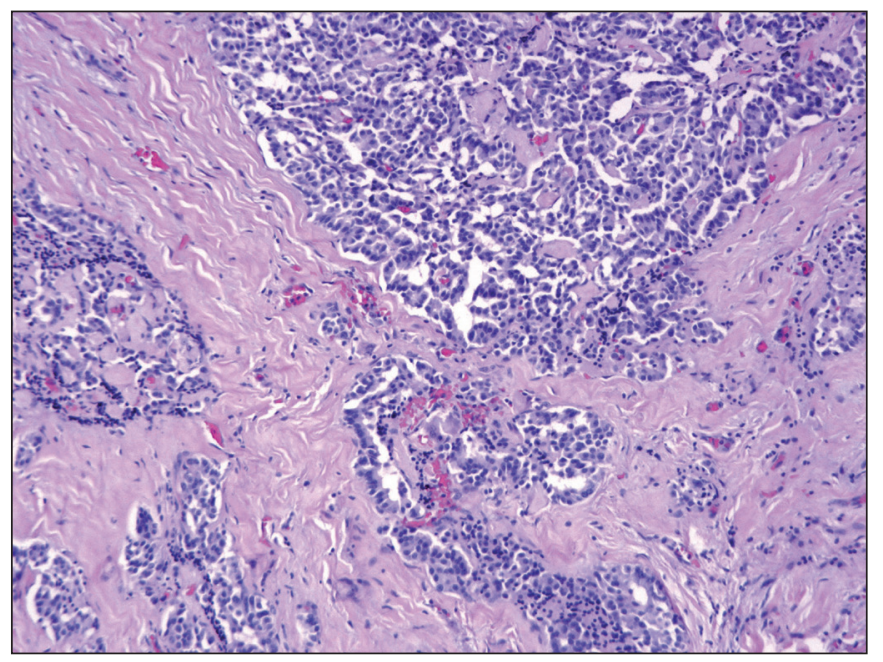

Figure 4: Medullary carcinoma demonstrating trabecular and nesting growth pattern with readily identifiable tumor associated fibrosis and amyloid deposition (H\&E; 10x).

encapsulated (106,107). Mendelsohn and Oertel reported a series of encapsulated thyroid lesions classified as atypical adenomas and showed that many of these were medullary cancers containing immunoreactive calcitonin. The follow-up in encapsulated medullary carcinomas indicates that they have a more benign prognosis than usual medullary tumors (108). The histologic differential diagnosis for the encapsulated variant includes hyalinizing trabecular adenoma. Immunohistochemistry for calcitonin will be positive in the medullary carcinoma, but not within the hyalinizing trabecular adenoma. In the past, some authors have used the term C-cell adenoma to describe encapsulated variants of medullary carcinoma; however, 


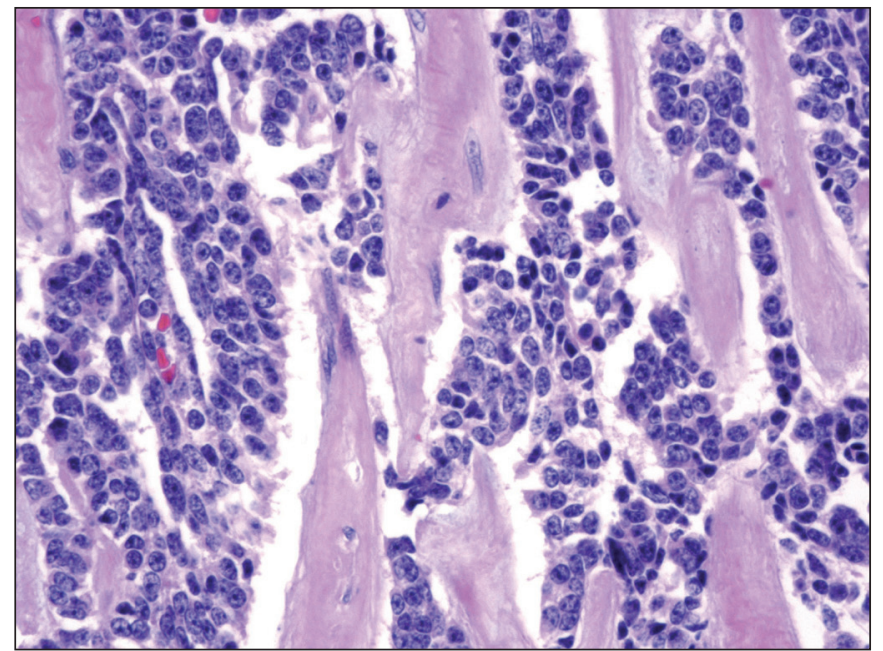

Figure 5: Round to oval spindle cells in medullary carcinoma with typical neuroendocrine nuclear chromatin and amyloid deposition (H\&E; 40x).

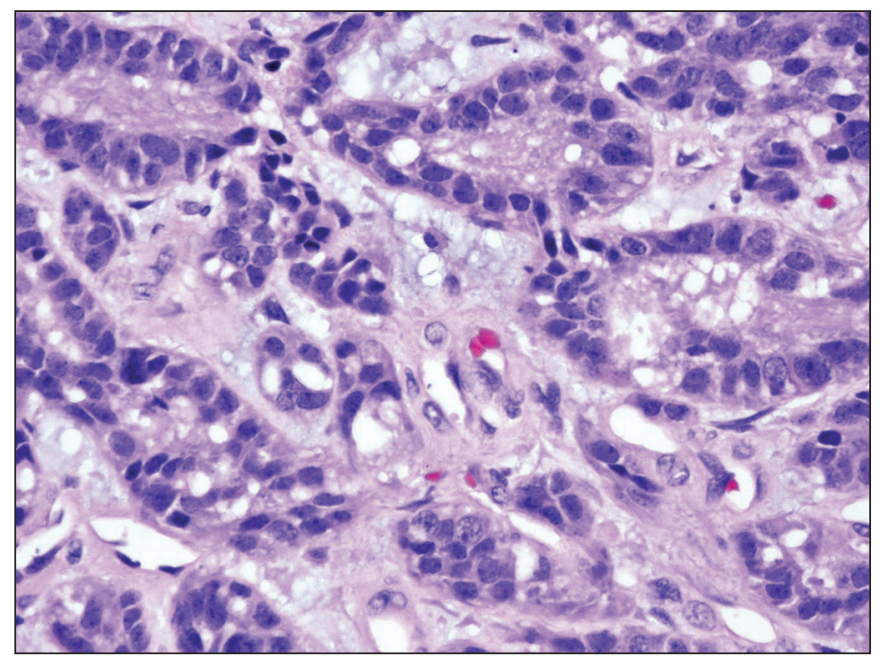

Figure 7: Pseudo-follicular or acinar/glandular growth pattern in medullary carcinoma (H\&E; 40x).

this terminology is not favored (109). The small cell variant of medullary carcinoma has also been described (110). These tumors look like pulmonary small cell carcinoma from which they need to be distinguished, if possible. The prognosis is worse than for typical medullary carcinoma. While calcitonin expression may not always be seen, the small cell variant of medullary carcinoma often expresses CEA and calcitonin gene-related peptide just as other types of medullary carcinoma do (110). The giant cell variant is rare and is characterized by large atypical cells admixed with areas of typical medullary carcinoma (111). Because of the presence of large atypical cells, this variant needs to be differentiated from anaplastic thyroid carcinoma, a tumor with a worse prognosis when compared to medullary

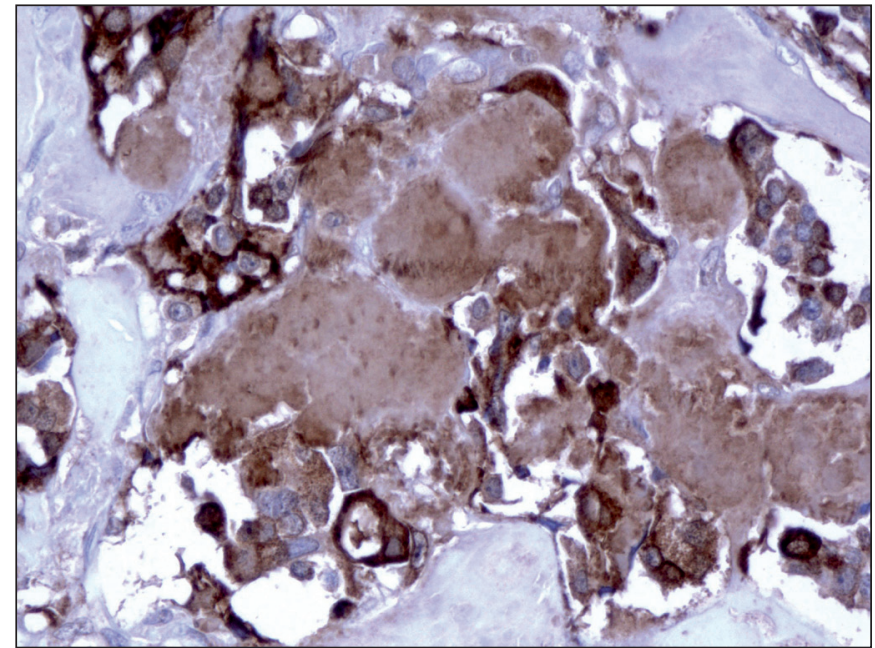

Figure 6: Calcitonin stain highlighting the tumor cells and amyloid deposits (due to procalcitonin) in medullary carcinoma (H\&E; 40x).

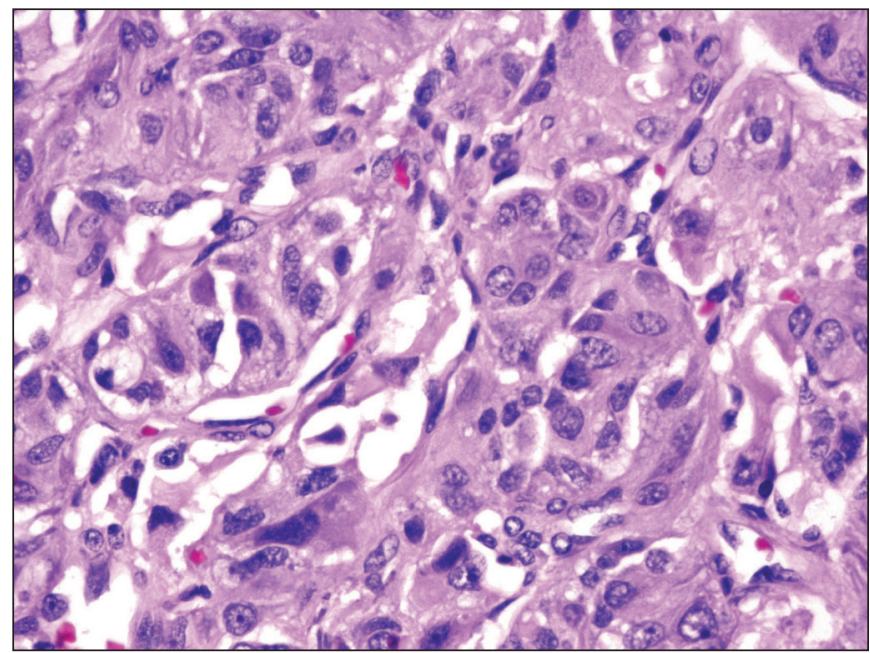

Figure 8: Tumor cells with abundant oncocytic cytoplasm in a case of medullary carcinoma (H\&E; 40x).

carcinoma. The clear cell variant is a rare form of medullary carcinoma and is characterized by cells with abundant clear cytoplasm (112). Immunohistochemical stains reveal the presence of calcitonin in the lesional cells. Differential diagnostic consideration for this variant includes follicular-derived neoplasms with clear cell cytoplasm as well as metastatic renal cell carcinoma. Other variants of medullary carcinoma include oncocytic (Figure 8) and squamous variants (113). Immunohistochemical stains are often needed to establish the correct diagnosis.

Up to $40 \%$ of medullary carcinomas contain mucin, most of which is extracellular, intracytoplasmic mucin can be seen in about $15 \%$ of medullary carcinomas (114). Rare tumor may contain melanin pigment, the significance of which is not 
known $(115,116)$. By immunohistochemistry, the majority of medullary carcinomas express low-molecular-weight cytokeratin, calcitonin, calcitonin gene-related peptide and TTF-1 (117) (Figure 9,10). In addition, many tumors express CEA, which may also be elevated in the serum (118). A variety of other peptides may be found in tumor cells including somatostatin, vasoactive intestinal peptide, and synaptophysin $(119,120)$. Some studies have also identified polysialic acid (neural cell adhesion molecule) in medullary carcinomas but not in other thyroid tumors (121).

Occasional lesions (and often these are small-cell type) do not contain immunoreactive calcitonin $(110,122)$. In order to accept a calcitonin-free tumor of the thyroid as a medullary carcinoma, it should arise in a familial setting or occur in a thyroid with unequivocal C-cell hyperplasia. Immunoreactivity for calcitonin gene-related peptide would add proof to the histogenetic nature of such a lesion. The existence of a true small cell nonmedullary neuroendocrine tumor of the thyroid is accepted.

\section{MIXED FOLLICULAR AND MEDULLARY CARCINOMA}

These controversial tumors show thyroglobulin and calcitonin immunoreactivity and ultrastructural evidence of differentiation along two cell lines (123-125) (Figure 11-14). Some of the series of these tumors may have been confusing, with trapping of follicles at the invading edge of the medullary carcinoma and diffusion of thyroglobulin into the medullary carcinoma; this may result in diagnosis of mixed tumors showing immunostaining for both hormones (126-129). Caution should be taken for making the diagnosis of mixed medullary and follicular-derived carcinomas.

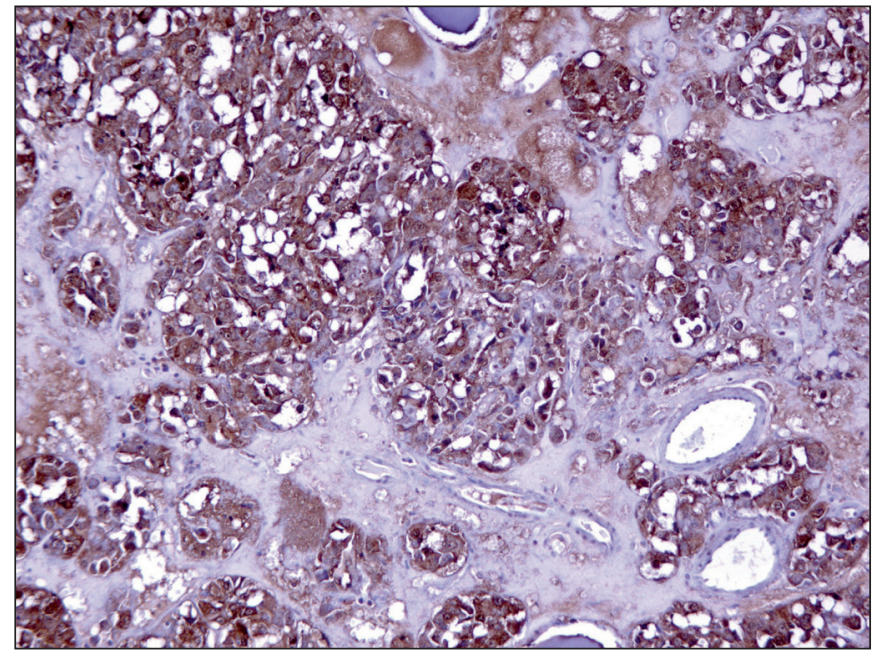

Figure 9: Calcitonin immunostain demonstrating strong and diffuse expression in medullary carcinoma (Immunoperoxidase, 20x).

\section{CYTOLOGIC DIAGNOSIS OF MEDULLARY THYROID CARCINOMA}

Medullary thyroid carcinoma (usually sporadic) can be detected during routine radiologic evaluation of thyroid gland either due to multiple nodule or screening of other lesions in the neck. The diagnosis of MTC can be made preoperatively by fine-needle aspiration biopsy (FNAB) (130-133).

By ultrasound MTC are solid, ovoid to round, hypoechoic lesions, which lack the "halo" sign, commonly encountered in follicular lesions. Up to $50 \%$ of medullary thyroid carcinoma demonstrate bright echogenic foci; indicative of deposits of calcium surrounded by amyloid. Cystic change is unusual for medullary thyroid carcinoma $(134,135)$.

FNAB specimens of medullary are often cellular and frequently show a heterogeneous morphology as seen in surgical pathology specimens. The tumor cells are arranged in either small cell groups, tissue fragments or as single cells. (Figure 15,16) The tissue fragments are usually of small size; papillary and follicular architecture has been described in aspirates of medullary carcinoma. In some cases the cells may be arranged in small cords and nests. Usually the lesional cells are either round to oval or spindle shaped (Figure 15-18). The cytoplasm is usually granular and up to $20 \%$ of cases show prominent eosinophilic granules in Romanowsky stained preparations; these occur in $5-10 \%$ of the neoplastic cells and contain calcitonin (Figure 17A,B). Interestingly, these granules are less prominent to absent in Papanicolaou stained preparations. The nuclei of the medullary carcinoma demonstrates coarse clumping of the nuclear chromatin with inconspicuous nucleoli; typical of

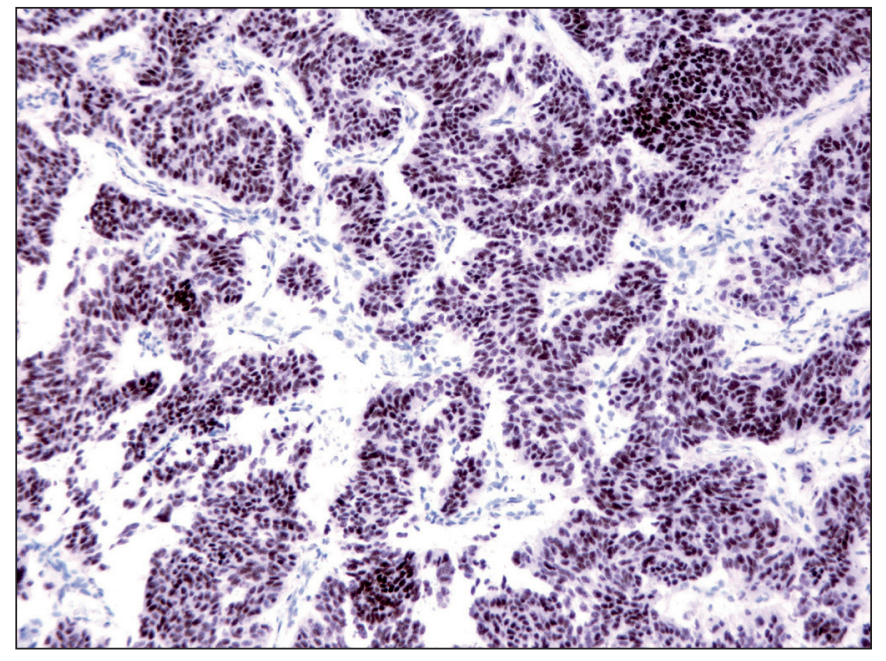

Figure 10: TTF-1 immunostain highlighting the nuclei of medullary carcinoma; this expression can be variable and can range from focal to diffuse (Immunoperoxidase; 10x). 

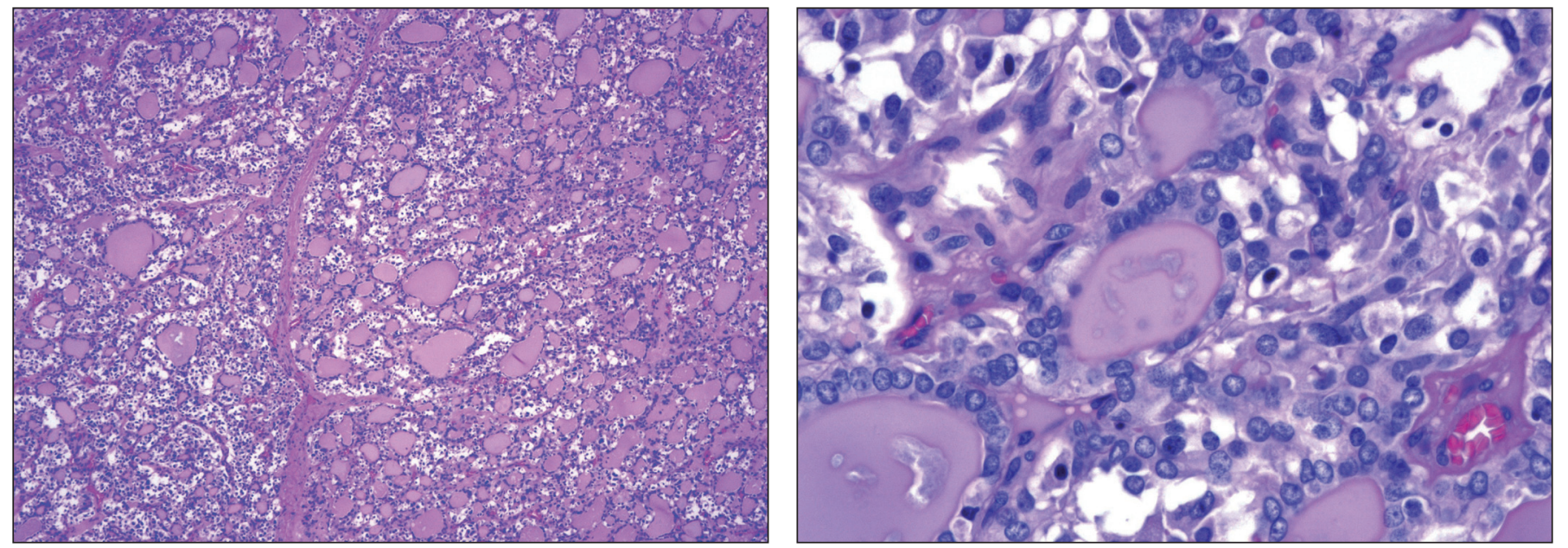

Figure 11 and 12: A case of mixed follicular variant of papillary thyroid carcinoma and medullary carcinoma demonstrating dual growth pattern i.e. follicular and nesting (H\&E; 10x \& 20x).
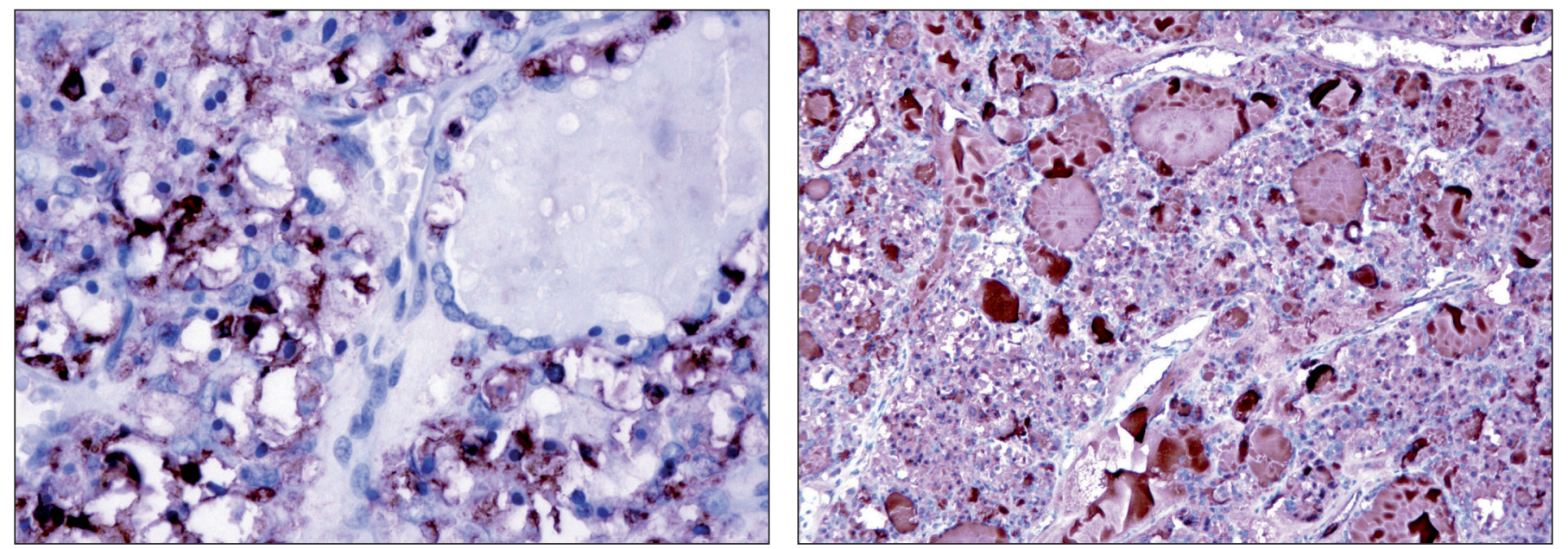

Figure 13 and 14: Calcitonin immunostaining highlighting the medullary component (Figure 13) and thyroglobulin highlighting the follicular variant of papillary thyroid carcinoma (Figure 14) (immunoperoxidase, 20x).
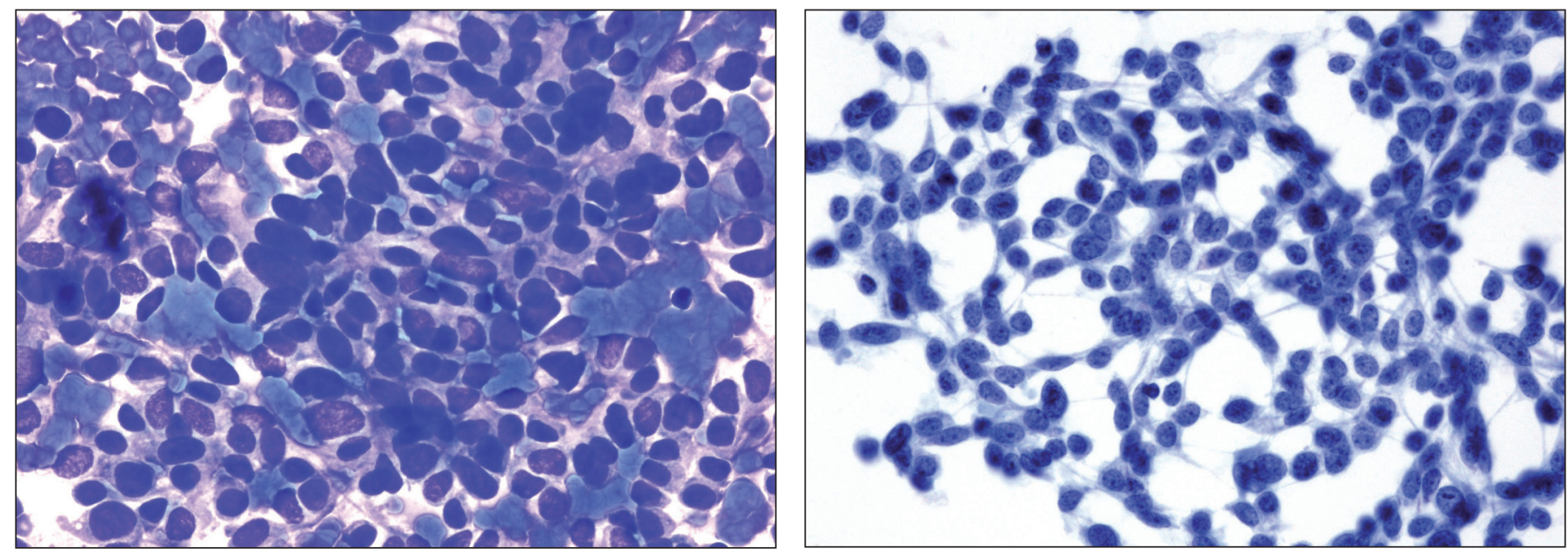

Figure 15 and 16: A fine-needle aspiration specimen of medullary thyroid carcinoma demonstrating cellular specimen consisting of round to oval tumor cells on both Diff-Quik ${ }^{\circledast}$ (Figure 15, 20x) and Papanicolaou (Figure 16, 20x). 
neuroendocrine tumors (Figure 18,19). Marked nuclear pleomorphism is not common; however, when present the cases are indistinguishable from aspirates of anaplastic thyroid carcinoma (Figure 19). Cytoplasmic intranuclear inclusions can also be seen in aspirates of medullary thyroid carcinoma (130,132,136-141).

In cases where a majority of the cells are round to oval in shape, the nucleus is usually situated eccentrically giving rise to a plasmacytoid appearance to tumor cells (Figure 17A,B). In cases with the prominent round cell pattern the tissue fragments are rare. Some cases of medullary carcinoma may only contain spindle cells and appears similar to a tumor of mesenchymal origin. These aspirates usually show cohesive groups of spindle cells with nucleus in eccentric location and occupying most of the cell. The cytoplasm of spindle shaped tumor cells is scant and stretched out in thin processes (Figure 18, 20). Medullary carcinoma mimicking small cell carcinoma has been reported in the literature. Intranuclear groves and inclusions can also be encountered in these cases $(136,142)$. Rarely, medullary carcinoma may also show intracytoplasmic mucin.

Amyloid can be seen in aspirates of medullary thyroid carcinoma as acellular material (easily highlighted with Romanowsky stain) in the form of strings, irregular shaped
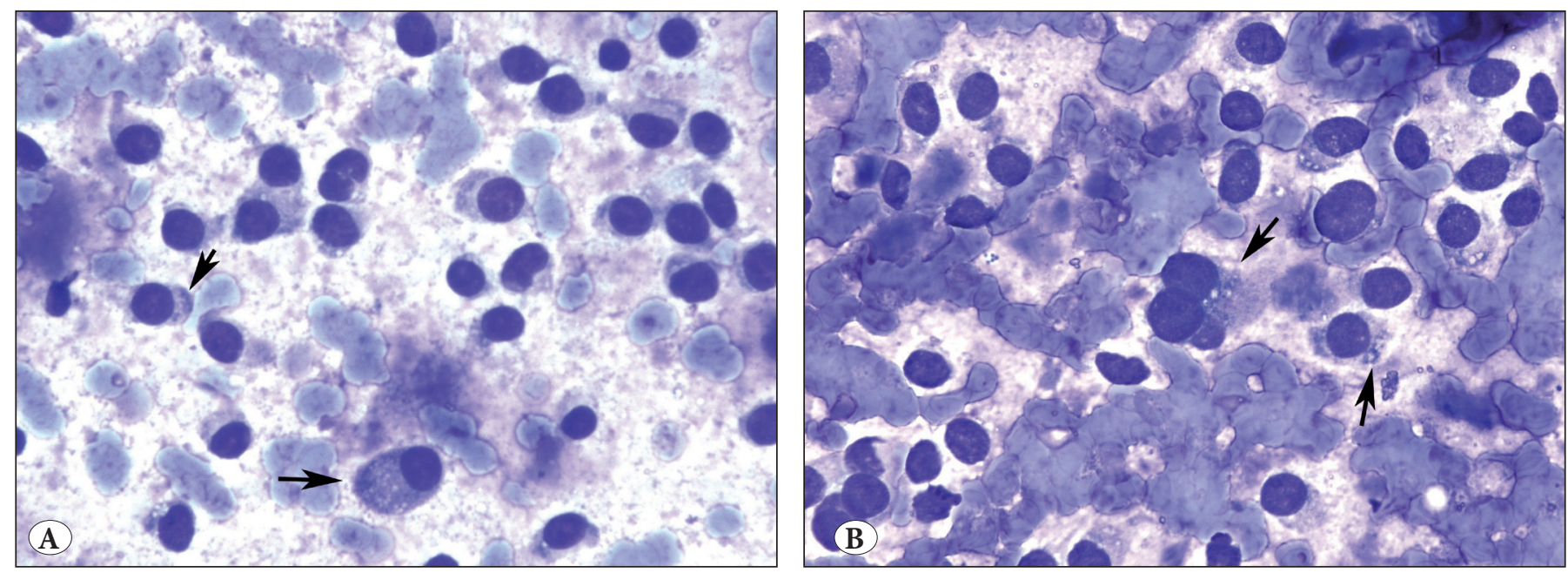

Figure 17: A) Plasmacytoid tumor cells in a fine needle aspiration specimen of medullary thyroid carcinoma (Diff-Quik ${ }^{\circledR}$ stain, $40 \mathrm{x}$ ). B) Notice the binucleated cells and prominent cytoplasmic granules (arrows) (Diff-Quik ${ }^{\oplus}$ stain, 40x).

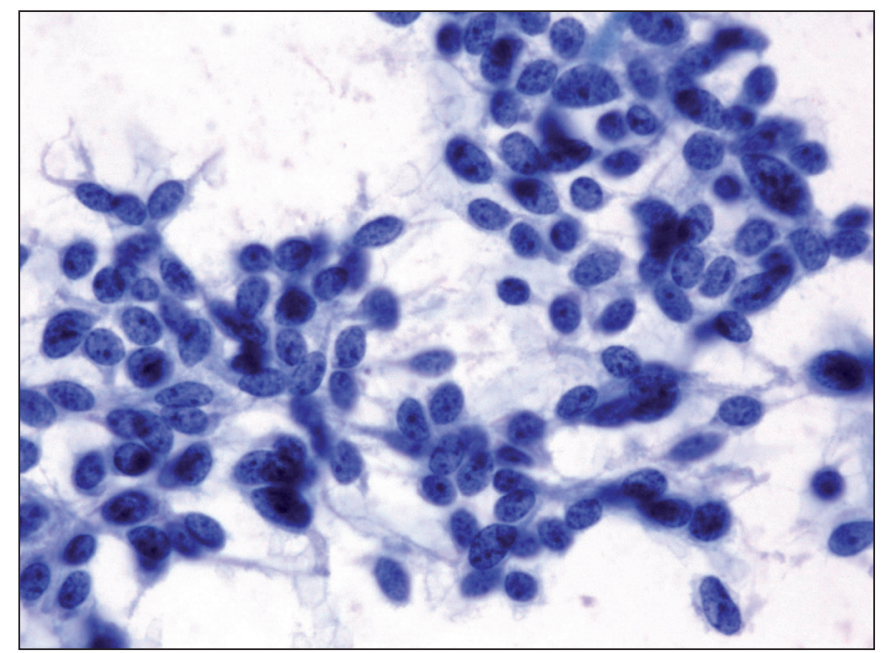

Figure 18: Round to oval cells in a fine needle aspiration specimen of medullary thyroid carcinoma. Notice the neuroendocrine nuclear chromatin (AKA salt and pepper distribution) and "wispy" elongated cytoplasmic extensions (Alcohol fixed Papanicolaou stained smear, 40x).

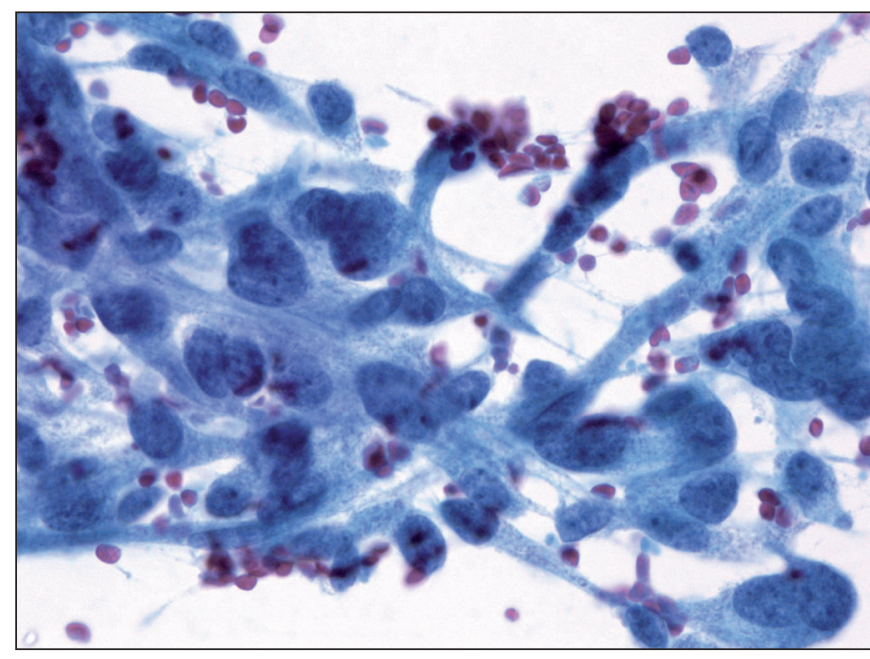

Figure 19: Cellular pleomorphism and bi-nucleation in a fine needle aspiration specimen of medullary thyroid carcinoma (Alcohol fixed Papanicolaou stained smear, 60x). 
or as round to oval fragments. It can be seen either with or without closely associated tumor cells (Figure 15). It can be difficult to distinguish amyloid from thick colloid; which is often encountered in neoplastic follicular proliferations. Amyloid can be highlighted with special stains (Congored) in cell block preparations $(143,144)$.

The cytologic impression can be confirmed by performing immunostains for calcitonin, (130) however, in some cases this may not be feasible due to scant specimens. In such cases it is prudent to recommend serum calcitonin levels to establish the diagnosis of medullary carcinoma $(138,144,145)$. Some authors have also suggested measuring

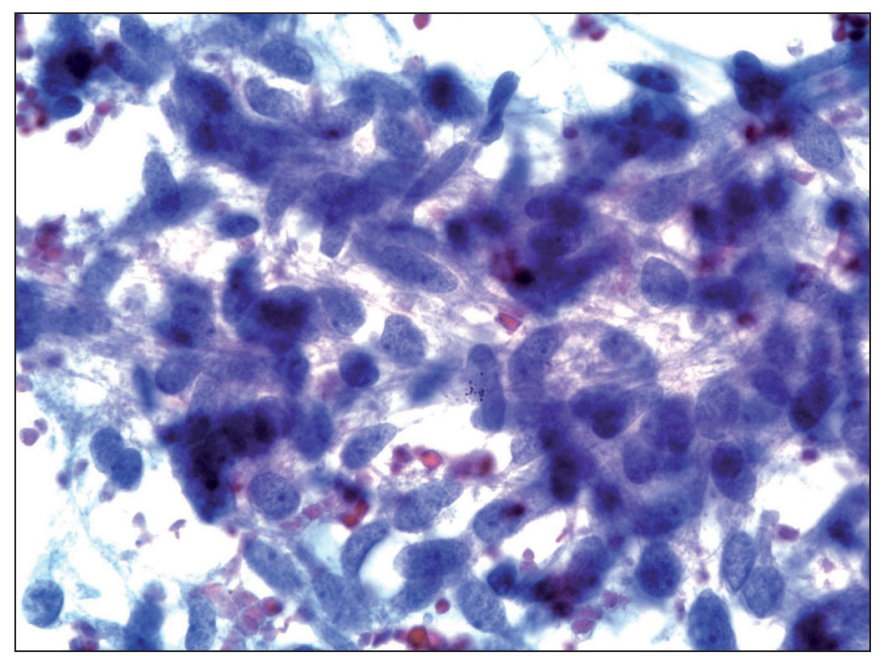

Figure 20: Spindle cell morphology in a fine needle aspiration specimen of medullary thyroid carcinoma (Alcohol fixed Papanicolaou stained smear, 60x).

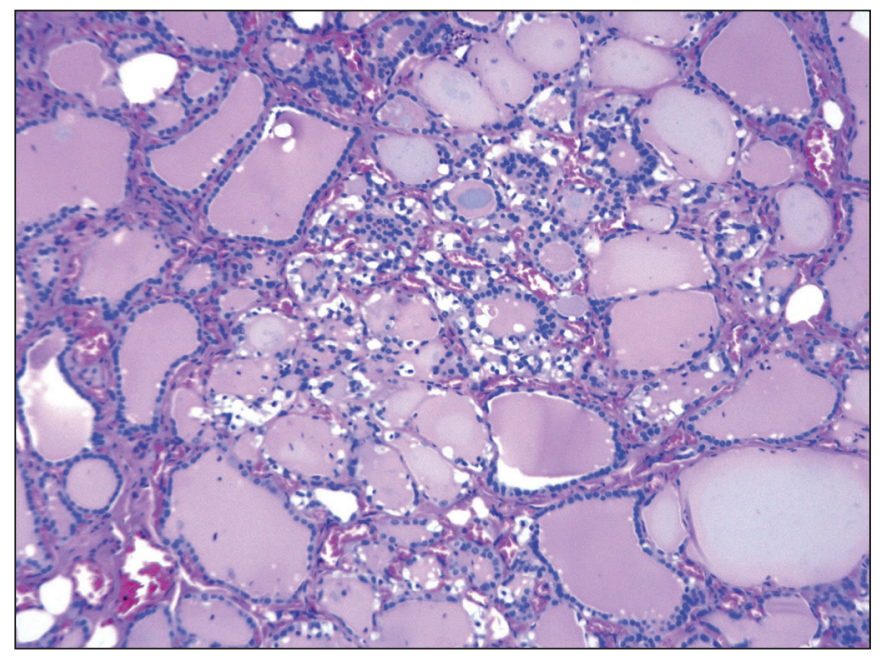

Figure 21: C-cell hyperplasia in a MEN2B patient; notice the readily identifiable $\mathrm{C}$-cells with clear cytoplasm in para-follicular location (H\&E; 20x). calcitonin levels in the FNAB rinse to diagnose primary and recurrent/metastatic MTC as an adjunct to cytomorphology $(146,147)$.

\section{C-CELL HYPERPLASIA}

The definition of C-cell hyperplasia is difficult. The lower limit of C-cell hyperplasia and the upper limit of normal C-cell mass are not clear $(17,36,148)$. Various studies show C-cell clusters in adults that, taken alone, could fit into the category of C-cell hyperplasia. Yet O'Toole and colleagues (16) and Gibson and colleagues (149) noted these clusters of C cells at autopsy in apparently endocrinologically normal individuals. Conversely, the lower limit of medullary carcinoma and upper limit of C-cell hyperplasia is difficult to define. DeLellis and Wolfe (150) state that $\mathrm{C}$-cell hyperplasia ranges from diffuse increase in the cells to nodules of C-cells replacing follicles, and once the basement membrane of the follicle is breached, medullary carcinoma should be diagnosed. However, Carney and associates (151) point out it is not always obvious that the basement membrane has been crossed.

In the classic case of C-cell hyperplasia, the lesion appears as multifocal areas of increased numbers of amphophilic large cells replacing follicular epithelium and also replacing follicles completely forming nodules (Figure 21,22). More specific definitions of C-cell hyperplasia include more than $50 \mathrm{C}$ cells per low-power field and more than $40 \mathrm{C}$ cells/cm 2 to more than $50 \mathrm{C}$ cells per 3 low-power fields $(152,153)$. With these definitions C-cell hyperplasia is not only seen in patients with MEN syndromes or familial medullary carcinoma (154), but also in patients with hyperparathyroidism, chronic hypercalcemia of other

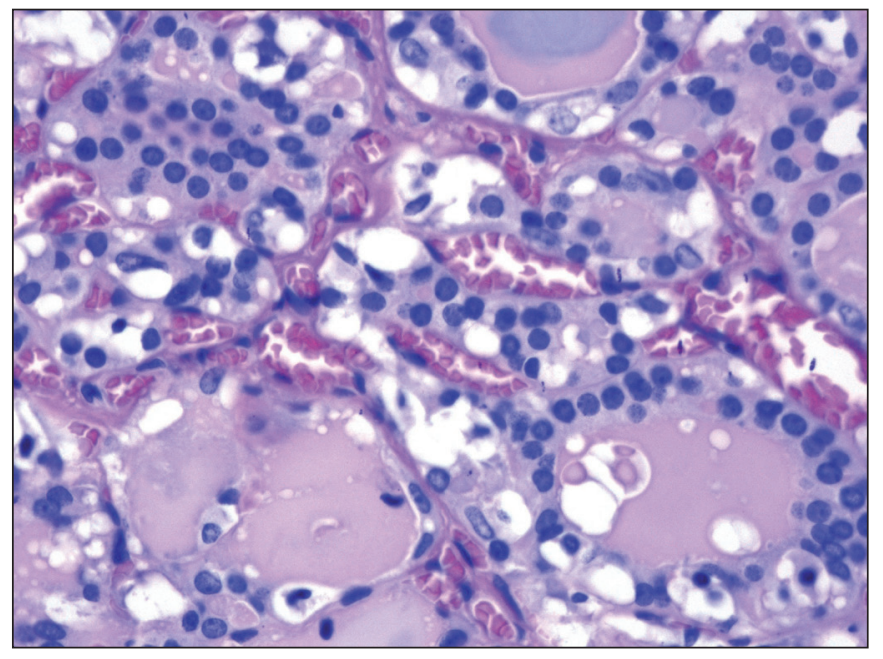

Figure 22: C-cell hyperplasia in MEN2B patients demonstrating hyperplastic C-cells with clear cytoplasm and overtaking the follicles (H\&E; 40x). 
causes, Hashimoto disease, in residual thyroid tissue following removal of medullary cancer (sporadic type), and even in thyroid tissue adjacent to non-medullary carcinomas $(153,155)$. In the mid-190s, the term "Neoplastic" C-cell hyperplasia was introduced to define a lesion precursor to familial MTC vs. reactive or secondary hyperplasia $(22,156)$.

Because C-cell hyperplasia may be associated with so many lesions, the exact significance using these various definitions cannot be determined. One of the best ways to distinguish C-cell hyperplasia is by routine histologic examination. C-cell hyperplasia associated with familial medullary carcinoma and MEN syndromes is readily observed on routine hematoxylin and eosin (H\&E) stains $(157,158)$. The cells are often large and show significant nuclear atypia as well as occasional features of medullary carcinoma. On the other hand, secondary C-cell hyperplasia is often only observed by immunohistochemical staining for calcitonin and quantitative analysis (Figure 23). The actual diagnosis of C-cell hyperplasia may therefore be made by routine histologic examination for the presence of $\mathrm{C}$ cells by H\&E stains. medullary microcarcinoma can be found in glands removed prophylactically because of positive genetic testing for RET mutations (159). These are similar to micropapillary carcinomas, in that, they measure equal to or less than $1.0 \mathrm{~cm}$. In the familial setting there is usually associated C-cell hyperplasia (160).

Interestingly, C-cell lesions including hyperplasia and medullary carcinoma can spontaneously occur in rodent species including mice and rats. It has been shown that a daily injection of Glucagon-like peptide-1 (GLP-1) receptor agonist, used for the treatment of adult onset diabetes raises

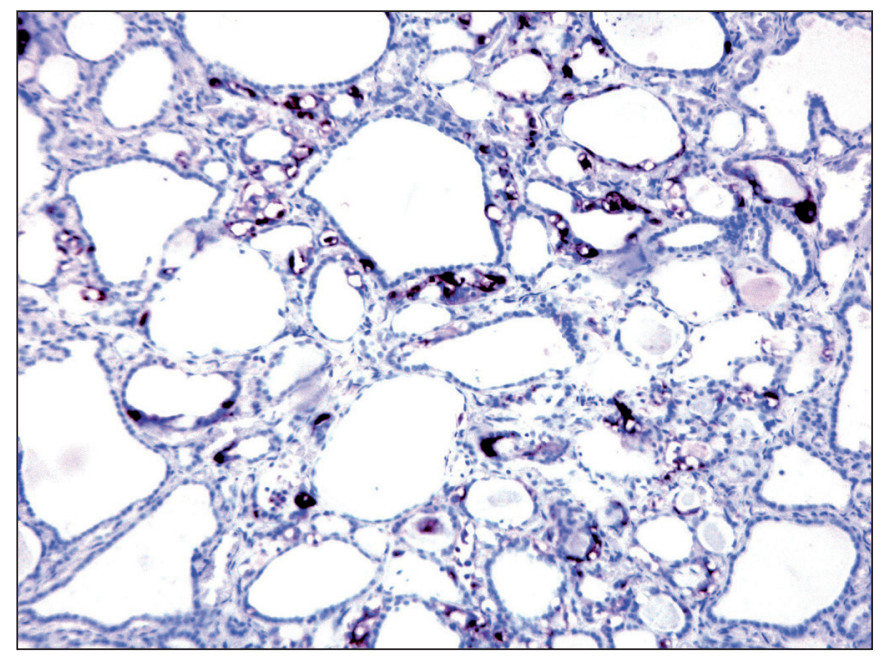

Figure 23: Calcitonin immunostain highlighting hyperplastic C-cells in a MEN2B patient (Immunoperoxidase; 10x).
cAMP in thyroid C-cells with increasing levels of calcitonin and upon long-term exposure leading to C-cell hyperplasia and medullary thyroid carcinoma. It is hypothesized that similar effects of GLP-1 agonists such as exenatide, liraglutide and others can occur in humans. At present there is neither firm evidence in favor of this hypothesis nor evidence strong enough to completely rule out this increased risk of C-cell lesions associated with GLP-1 agonist treatment in type 2 diabetes $(161,162)$.

\section{MEDULLARY MICROCARCINOMA}

Medullary microcarcinoma is defined as sporadic or familial tumors measuring $1.0 \mathrm{~cm}$ or less in thyroid lobes or glands removed for benign nodules or for nonmedullary cancer $(22,163,164)$ (Figure 24). These lesions show a rounded or focally infiltrative pattern of growth, may contain amyloid, and are not necessarily associated with C-cell hyperplasia (22). The glands frequently show chronic lymphocytic thyroiditis (165). In the absence of symptomatic hypercalcitoninemia, or lymph node metastases, these lesions are cured by their simple removal $(160,165)$.

\section{PROGNOSIS, AND RISK STRATIFICATION BASED ON GENETIC TESTING}

From the clinical standpoint, stage is the most important variable for prognosis $(73,166-169)$. A tumor confined to the thyroid without nodal or distant metastases is associated with prolonged survival $(73,169)$. Several workers have found that younger patients (under age 40), especially women, fare somewhat better than the whole group of medullary cancer patients $(167,170)$. Patients who are discovered by screening, because they are members of

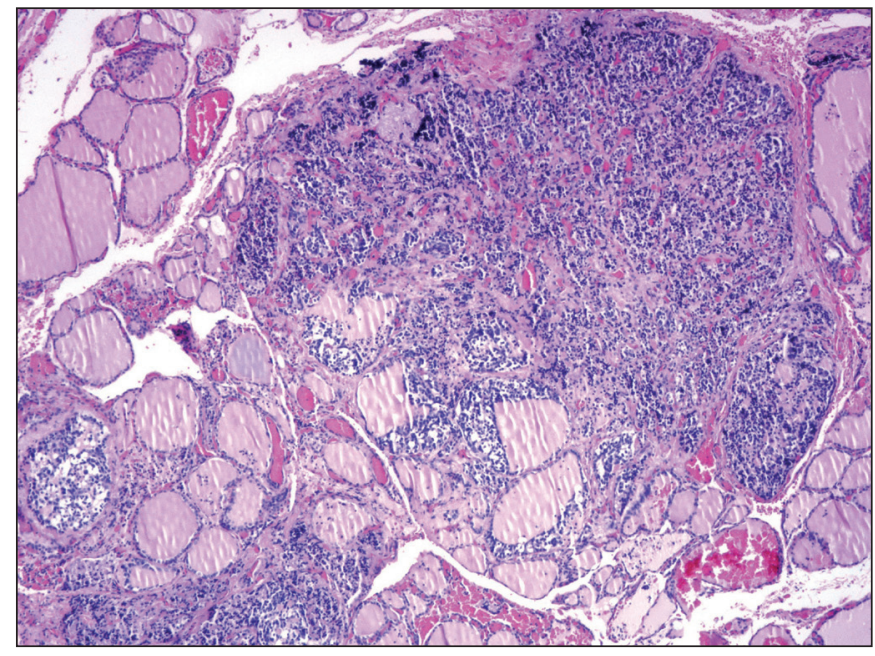

Figure 24: Medullary microcarcinoma with focal infiltrative growth pattern (H\&E; 10x). 
affected families often have very small tumors and can be cured by thyroidectomy (19,171-173). Patients with Sipple syndrome tend to have less aggressive tumors than the sporadic group; whereas, the patients with MEN type IIB have aggressive lesions $(24,73,173,174)$. Pathologic features that have been related to prognosis include tumor pattern, amyloid content, pleomorphism, necrosis, and mitotic activity $(20,73,106)$. Medullary carcinomas with small cell features and those tumors with extensive areas of necrosis, marked cellular pleomorphism, and high mitotic activity are associated with poor prognosis $(20,24,106)$. Encapsulated tumors and tumors with uniform cytology and abundant amyloid tend to be indolent tumors. Schroder and colleagues found that aneuploidy was associated with a poor outcome (175).

The predictive testing for MEN2 based on genetic mutation testing was first developed by Chi and Wells.(176) This was further supported by a study of a cohort of 477 kindred affected by any MEN 2 syndrome, performed by the International RET Consortium (IRC).(177) To date, the RET-mutation testing detects nearly $100 \%$ of the carriers and is the standard of care for all first-degree relatives of patients with newly diagnosed MTC. $(19,177)$ However, due to the variable clinical effects of $R E T$-mutations, a risk based classification scheme was needed to guide management of MTC. Various international workgroup and societies have recommended evidence-based guidelines to provide strategies in clinical care of patients with MTC. In 2009, American Thyroid Association (ATA) provided guidelines on the clinical workup and timing of prophylactic thyroidectomy and extent of surgery based on 4-risk levels (A-D) developed by employing the genotype-phenotype correlation (178) (Table II). The ATA-level D consists of most aggressive mutations and carries the highest risk of developing MTC. These mutations, which are typically seen in MEN2B, are associated with the youngest age at disease onset and the highest risk of mortality. ATA-level C mutations (codon 634) are associated with a slightly lower risk, yet the MTC in patients with these mutations is still quite aggressive and may present at an early age. ATA-level $\mathrm{A}$ and level B mutations are associated with a lower risk as compared to level C and level D mutation carriers. However, the risk of MTC is still substantially higher as compared to the risk in general population and consideration of riskreducing thyroidectomy is warranted (178).

Recently, the ATA revised these guidelines and recommended in order to avoid confusion among these four risk categories (24) (Table II). The category D is now named as "Highest Risk (ATA-HST)" and C to "High Risk(ATA-H)" (Table). The categories A and B are combined into a new category designated as "Moderate Risk (ATA-MOD)". The ATA-HST category includes patients with MEN2B and the RET codon M918T mutation, ATA-H consists of patients with RET Codon C634 mutation, and ATA-MOD includes those with RET codon mutations other that M918T and C634. Based on these ATA-risk categories prophylactic thyroidectomy has been recommended in children who have inherited a mutated RET-allele, as most thyroids in these on histologic examination will demonstrate C-cell hyperplasia or medullary carcinoma. It is recommended that prophylactic thyroidectomy be performed in the first year of life in children in the ATA-HST category i.e. RET codon M918T mutation, and at age 5 or earlier based on determination of serum calcitonin levels in ATA-H category. Children in ATA-MOD category should have physical examination, ultrasound of the neck and serum calcitonin measurements commencing around at age 5 to decide the timing of prophylactic thyroidectomy (24).

Table II: American Thyroid Association Risk Assessment 2015 / 2009

\begin{tabular}{|c|c|c|c|c|}
\hline $\begin{array}{c}\text { ATA Risk Level Categories } \\
\text { 2015 / 2009 \& } \\
\text { Common RET Mutations }\end{array}$ & Gen-Testing & Neck US & Serum Cal & Prophylactic Thyroidectomy \\
\hline $\begin{array}{c}\text { Moderate / A \& B } \\
\text { exon 10: 533, 611, 620; exon 11: 631, } \\
\text { 666; exon 13: 768, 790; exon 14: 804; } \\
\text { exon 16: 912 }\end{array}$ & $<3-5 \mathrm{y}$ & $>3-5 \mathrm{y}$ & $>3-5 \mathrm{y}$ & $\begin{array}{c}\text { May delay beyond age 5 if normal } \\
6 \text { month or annual Cal \& neck } \\
\text { US, indolent MTC history, family } \\
\text { preference }\end{array}$ \\
\hline $\begin{array}{c}\text { High / C } \\
\text { exon 11: 634; exon 15: A883 }\end{array}$ & $<3-5 \mathrm{y}$ & $>3-5 \mathrm{y}$ & $>3-5 \mathrm{y}$ & Consider before age 5 \\
\hline $\begin{array}{c}\text { Highest / D } \\
\text { exon 16: } 918 \mathrm{~T}\end{array}$ & Immediately & Immediately & Immediately & Immediately \\
\hline
\end{tabular}

Gen: Genetic, US: Ultrasound, Cal: Calcitonin. 


\section{TREATMENT}

All patients diagnosed with MTC should undergo total thyroidectomy with central compartment lymphadenectomy. It has been shown that up to $45 \%$ of the patients have metastatic MTC deposits in central compartment; and excision of these lymph nodes at first procedure can dramatically decrease the recurrence rates. The lateral neck lymph nodes are usually evaluated preoperatively by ultrasound examination and the metastases can be confirmed by FNAB followed by compartment oriented lymph node dissection $(24,41,179-181)$.

Distant metastases are not uncommon in MTC and can occur to lung, liver, bone and rarely brain and other body sites (182-189). However, despite widespread metastases MTC is a slow-growing tumor, which leads to opportunities for targeted therapy. These therapies are based on the fact that all patients with MEN2A and MEN2B and half of sporadic MTC patients have RET mutations; furthermore $18-80 \%$ patients with sporadic MTC have RAS mutations. In addition, VEGF receptors are often overexpressed in tumor cells and the vascular endothelium within the tumor. Recently, several investigators have shown varying successes in phase 1, II and III clinical trails employing several tyrosine kinase inhibitors (190-192).

Vandetanib (Caprelsa) and cabozantinib (Cometriq) are tyrosine kinase inhibitors approved by the U.S. Food and Drug Administration (FDA) for progressive, metastatic medullary thyroid cancer. These agents target various tyrosine kinases including MET, RET, and VEGFR-2 (190-195).

The FDA approval of vandetanib is based on the results of a phase III, double-blind trial that showed a statistically significant improvement in progression-free survival (PFS) when compared to those randomized to placebo. The median progression-free survival was 16.4 months in the placebo arm and at least 22.6 months in the vandetanib arm $(196,197)$.

The approval for cabozantinib was based on the EXAM clinical trial, an international, multicenter, randomized study that included 330 patients with progressive, metastatic medullary thyroid carcinoma. A statistically significant prolongation in progression-free survival was seen with cabozantinib compared with placebo (11.2 vs 4.0 months; $\mathrm{p}<0.0001)$. Partial responses were observed only among patients in the active treatment arm $(27 \%$ vs $0 \%$; $p<0.0001)$, and more patients in the cabozantinib group than in the placebo group were alive and free of disease progression at 1 year $(47.3 \%$ vs $7.2 \%)$. Median duration of response was 14.7 months $(24,198,199)$.
It is important to realize that these treatments are not without significant short-term toxicity and no large cohort data is available on long-term toxicity of these agents. Therefore, a majority of these treatments are only restricted to carefully monitored protocols for patients with significant tumor burden and disease progression $(24,191,200-202)$.

\section{CONFLICT OF INTEREST}

The authors have declared no conflict of interest.

\section{REFERENCES}

1. Nonidez FJ. Further observations on the parafollicular cells of the mammalian thyroid. Anat Rec. 1932;53:339-47.

2. Copp DH, Cockcroft DW, Kueh Y. Calcitonin from ultimobranchial glands of dogfish and chickens. Science. 1967;158:924-5.

3. Hirsch EF. Carcinoma of the thyroid gland: Report of 94 cases Med Ann Dist Columbia. 1963;32:498-501.

4. Foster GV, Baghdiantz A, Kumar MA, Slack E, Soliman HA, Macintyre I. Thyroid origin of calcitonin. Nature. 1964;202:13035.

5. Pearse AG. The cytochemistry of the thyroid $\mathrm{C}$ cells and their relationship to calcitonin. Proc R Soc Lond B Biol Sci. 1966;164:478-87.

6. Bussolati G, Pearse AG. Immunofluorescent localization of calcitonin in the ' $\mathrm{C}$ ' cells of pig and dog thyroid. J Endocrinol. 1967;37:205-9.

7. Horn R. Carcinoma of the thyroid. Description of a distinctive morphological variant and report of seven cases. Cancer. 1951;4:697-707.

8. Hazard J, Hawk W, Crile G. Medullary (solid) carcinoma of the thyroid: A clinicopathologic entity. J Clin Endocrinol Metab. 1959;19:152-61.

9. Williams E. Histogenesis of medullary carcinoma of the thyroid. J Clin Pathol. 1966;19:114-8.

10. Meyer JS, Abdel-Bari W. Granules and thyrocalcitonin-like activity in medullary carcinoma of the thyroid gland. N Engl J Med. 1968;278:523-9.

11. Bussolati G, Foster GV, Clark MB, Pearse AG. Immunofluorescent localisation of calcitonin in medullary C-cell thyroid carcinoma, using antibody to the pure porcine hormone. Virchows Arch B Cell Pathol. 1969; 2:234-8.

12. Leitz H. C-cells: Source of calcitonin. Curr Top Pathol 1971;55:109-46.

13. Weston J. The regulation of normal and abnormal neural crest cell development. Adv Neurol. 1981; 29:77-95.

14. Wolfe H, DeLellis R, Voelkel E, Tashjian A. Distribution of calcitonin containing cells in the normal neonatal human thyroid gland: A correlation of morphology with peptide content. J Clin Endocrinol Metab. 1975; 41:1076-81.

15. Wolfe H, Voelkel E, Tashjian A. Distribution of calcitonin containing cells in the normal adult human thyroid gland: A correlation of morpholohy and peptide content. J Clin Endocrinol Metab. 1974;38:688-94. 
16. O’Toole K, Fenoglio-Preiser C, Pushparaj N. Endocrine changes associated with the human aging process. III. Effect of age on the number of calcitonin immunoreactive cells in the thyroid gland. Hum Pathol. 1985;16:991-1000.

17. DeLellis RA, Nunnemacher G, Bitman WR, Gagel RF, Tashjian AH Jr, Blount M, Wolfe HJ. C-cell hyperplasia and medullary thyroid carcinoma in the rat. An immunohistochemical and ultrastructural analysis. Lab Invest. 1979;40:140-54.

18. Albores-Saavedra J, LiVolsi VA, Williams ED. Medullary carcinoma. Semin Diagn Pathol. 1985;2:137-46.

19. Wells SA, Jr., Franz C. Medullary carcinoma of the thyroid gland. World J Surg. 2000;24:952-6.

20. Matias-Guiu X, De Lellis R. Medullary thyroid carcinoma: A 25year perspective. Endocr Pathol. 2014;25:21-9.

21. Eng C. Seminars in medicine of the Beth Israel Hospital, Boston. The RET proto-oncogene in multiple endocrine neoplasia type 2 and Hirschsprung's disease. N Engl J Med. 1996 Sep 26;335:94351 .

22. Etit D, Faquin WC, Gaz R, Randolph G, DeLellis RA, Pilch BZ. Histopathologic and clinical features of medullary microcarcinoma and C-cell hyperplasia in prophylactic thyroidectomies for medullary carcinoma: A study of 42 cases. Arch Pathol Lab Med. 2008;132:1767-73.

23. Wells SA, Jr., Pacini F, Robinson BG, Santoro M. Multiple endocrine neoplasia type 2 and familial medullary thyroid carcinoma: An update. J Clin Endocrinol Metab. 2013;98:314964 .

24. Wells SA, Jr., Asa SL, Dralle H, Elisei R, Evans DB, Gagel RF, Lee NY, Machens A, Moley JF, Pacini F, Raue F, Frank-Raue K, Robinson B, Rosenthal MS, Santoro M, Schlumberger M, Shah MHM, Waguespack SG. Revised american thyroid association guidelines for the management of medullary thyroid carcinoma. Thyroid. 2015;25:567-610.

25. Takahashi M, Ritz J, Cooper GM. Activation of a novel human transforming gene, ret, by DNA rearrangement. Cell. 1985;42:581-8.

26. Durbec P, Marcos-Gutierrez CV, Kilkenny C, Grigoriou M, Wartiowaara K, Suvanto P, Smith D, Ponder B, Costantini F, Saarma M. GDNF signalling through the Ret receptor tyrosine kinase. Nature. 1996;381:789-93.

27. Nosrat CA, Tomac A, Hoffer BJ, Olson L. Cellular and developmental patterns of expression of Ret and glial cell linederived neurotrophic factor receptor alpha mRNAs. Exp Brain Res. 1997;115:410-22.

28. Trupp M, Arenas E, Fainzilber M, Nilsson AS, Sieber BA, Grigoriou M, Kilkenny C, Salazar-Grueso E, Pachnis V, Arumae U. Functional receptor for GDNF encoded by the c-ret protooncogene. Nature. 1996;381:785-9.

29. Mathew CG, Chin KS, Easton DF, Thorpe K, Carter C, Liou GI, Fong SL, Bridges CD, Haak H, Kruseman AC. A linked genetic marker for multiple endocrine neoplasia type $2 \mathrm{~A}$ on chromosome 10. Nature. 1987;328:527-8

30. Simpson NE, Kidd KK, Goodfellow PJ, McDermid H, Myers S, Kidd JR, Jackson CE, Duncan AM, Farrer LA, Brasch $\mathrm{K}$. Assignment of multiple endocrine neoplasia type 2A to chromosome 10 by linkage. Nature. 1987;328:528-30.
31. Santoro M, Rosati R, Grieco M, Berlingieri MT, D’Amato GL, de Franciscis V, Fusco A. The ret proto-oncogene is consistently expressed in human pheochromocytomas and thyroid medullary carcinomas. Oncogene. 1990;5:1595-8.

32. Asa SL. How familial cancer genes and environmentally induced oncogenes have changed the endocrine landscape. Mod Pathol. 2001;14:246-53.

33. Santoro M, Melillo RM, Carlomagno F, Vecchio G, Fusco A. Minireview: RET: Normal and abnormal functions. Endocrinology. 2004;145:5448-51.

34. Santoro M, Carlomagno F, Romano A, Bottaro DP, Dathan NA, Grieco M, Fusco A, Vecchio G, Matoskova B, Kraus MH. Activation of RET as a dominant transforming gene by germline mutations of MEN2A and MEN2B. Science. 1995;267:381-3.

35. Santoro M, Carlomagno F. Central role of RET in thyroid cancer. Cold Spring Harb Perspect Biol. 2013;5:a009233.

36. Asa SL. C-cell lesions of the thyroid. Pathol Case Rev. 1997;2:2107.

37. Heptulla RA, Schwartz RP, Bale AE, Flynn S, Genel M. Familial medullary thyroid carcinoma: Presymptomatic diagnosis and management in children. J Pediatr. 1999;135:327-31.

38. Gimm O, Sutter T, Dralle H. Diagnosis and therapy of sporadic and familial medullary thyroid carcinoma. J Cancer Res Clin Oncol. 2001;127:156-65.

39. Massoll N, Mazzaferri EL. Diagnosis and management of medullary thyroid carcinoma. Clin Lab Med. 2004;24:49-83.

40. Gagel RF, Melvin KE, Tashjian AH Jr, Miller HH, Feldman ZT, Wolfe HJ, DeLellis RA, Cerviskinner S, Reichlin S. Natural history of the familial medullary thyroid carcinomapheochromocytoma syndrome and the identification of preneoplastic stages by screening studies: A five-year report. Trans Assoc Am Physicians. 1975;88:177-191.

41. Abraham DT, Low TH, Messina M, Jackson N, Gill A, Chou AS, Delbridge L, Learoyd D, Robinson BG, Sidhu S, Sywak M. Medullary thyroid carcinoma: Long-term outcomes of surgical treatment. Ann Surg Oncol. 2011;18:219-25.

42. Bussolati G, van Noorden S, Bordi C. Calcitonin- and ACTHproducing cells in a case of medullary carcinoma of the thyroid. Immunofluorescence investigations. Virchows Arch A Pathol Pathol Anat. 1973;360:123-7.

43. Kakudo K, Miyauchi A, Ogihara T, Takai S, Kitamura $\mathrm{H}$ Kumahara Y, Kawaoi A. Medullary carcinoma of the thyroid with ectopic ACTH syndrome. Acta Pathol Jpn. 1982;32:793800 .

44. Mertens PR, Goretzki PE, Keck E. cAMP-synthesis in a medullary thyroid carcinoma cell line: Response to adrenergic agents and prostaglandines. Exp Clin Endocrinol Diabetes. 1999;107:48895.

45. Choi HS, Kim MJ, Moon $\mathrm{CH}$, Yoon JH, Ku HR, Kang GW Na, II, Lee SS, Lee BC, Park YJ, Kim HI, Ku YH. Medullary thyroid carcinoma with ectopic adrenocorticotropic hormone syndrome. Endocrinol Metab. (Seoul) 2014;29:96-100.

46. Santoro M, Melillo RM, Carlomagno F, Visconti R, De Vita G, Salvatore G, Fusco A, Vecchio G. Different mutations of the RET gene cause different human tumoral diseases. Biochimie. 1999;81:397-402. 
47. Eng C, Smith DP, Mulligan LM, Nagai MA, Healey CS, Ponder MA, Gardner E, Scheumann GF, Jackson CE, Tunnacliffe A. Point mutation within the tyrosine kinase domain of the RET proto- oncogene in multiple endocrine neoplasia type $2 \mathrm{~B}$ and related sporadic tumours. Hum Mol Genet. 1994;3:237-41.

48. Frank-Raue K, Dohring J, Scheumann G, Rondot S, Lorenz A, Schulze E, Dralle H, Raue F, Leidig-Bruckner G. New mutations in the RET protooncogene-L881V - associated with medullary thyroid carcinoma and -R770Q - in a patient with mixed medullar/follicular thyroid tumour. Exp Clin Endocrinol Diabetes. 2010;118:550-3.

49. Vaclavikova E, Kavalcova L, Skaba R, Dvorakova S, Macokova P, Rouskova B, Bendlova B. Hirschsprung's disease and medullary thyroid carcinoma: 15-year experience with molecular genetic screening of the RET proto-oncogene. Pediatr Surg Int. 2012;28:123-8.

50. Sharma BP, Saranath D. RET gene mutations and polymorphisms in medullary thyroid carcinomas in Indian patients. J Biosci. 2011;36:603-11.

51. Elisei R, Cosci B, Romei C, Bottici V, Renzini G, Molinaro E, Agate L, Vivaldi A, Faviana P, Basolo F, Miccoli P, Berti P, Pacini F, Pinchera A. Prognostic significance of somatic RET oncogene mutations in sporadic medullary thyroid cancer: A 10-year follow-up study. J Clin Endocrinol Metab. 2008;93:682-7.

52. Sipple J. The association of pheochromocytoma with carcinoma of the thyroid gland. Am J Med. 1961;31:163-6.

53. Jansson S, Hansson G, Salander H, Stenstrom G, Tisell L. Prevalence of C-cell hyperplasia and medullary thyroid carcinoma in a consecutive series of pheochormocytoma patients. World J Surg. 1984;8:493-500.

54. Borrello MG, Smith DP, Pasini B, Bongarzone I, Greco A, Lorenzo MJ, Arighi E, Miranda C, Eng C, Alberti L. RET activation by germline MEN2A and MEN2B mutations. Oncogene. 1995; 11:2419-27.

55. Eichhorn JH. Medullary carcinoma, provocative now as then. Semin Diagn Pathol. 2004;21:65-73.

56. Schuffenecker I, Virally-Monod M, Brohet R, Goldgar D, Conte-Devolx B, Leclerc L, Chabre O, Boneu A, Caron J, Houdent C, Modigliani E, Rohmer V, Schlumberger M, Eng C, Guillausseau PJ, Lenoir GM. Risk and penetrance of primary hyperparathyroidism in multiple endocrine neoplasia type 2A families with mutations at codon 634 of the RET protooncogene. Groupe D'etude des Tumeurs a Calcitonine. J Clin Endocrinol Metab. 1998;83:487-91.

57. Chang CF, Yang WS, Su YN, Wu IL, Chang TC. Mutational spectrum of multiple endocrine neoplasia type 2 and sporadic medullary thyroid carcinoma in taiwan. J Formos Med Assoc. 2009;108:402-8.

58. Rothberg AE, Raymond VM, Gruber SB, Sisson J. Familial medullary thyroid carcinoma associated with cutaneous lichen amyloidosis. Thyroid. 2009;19:651-5.
59. Romei C, Mariotti S, Fugazzola L, Taccaliti A, Pacini F, Opocher G, Mian C, Castellano M, degli Uberti E, Ceccherini I, Cremonini N, Seregni E, Orlandi F, Ferolla P, Puxeddu E, Giorgino F, Colao A, Loli P, Bondi F, Cosci B, Bottici V, Cappai A, Pinna G, Persani L, Verga U, Boscaro M, Castagna MG, Cappelli C, Zatelli MC, Faggiano A, Francia G, Brandi ML, Falchetti A, Pinchera A, Elisei R, Ita MENn. Multiple endocrine neoplasia type 2 syndromes (MEN 2): Results from the ItaMEN network analysis on the prevalence of different genotypes and phenotypes. Eur J Endocrinol. 2010;163:301-8.

60. Hu MI. Updates in the management of medullary thyroid cancer. Clin Adv Hematol Oncol. 2011;9:391-4.

61. Krampitz GW, Norton JA. RET gene mutations (genotype and phenotype) of multiple endocrine neoplasia type 2 and familial medullary thyroid carcinoma. Cancer. 2014;120:1920-31.

62. Sromek M, Czetwertynska M, Skasko E, Zielinska J, Czapczak $\mathrm{D}$, Steffen J. The frequency of selected polymorphic variants of the RET gene in patients with medullary thyroid carcinoma and in the general population of central Poland. Endocr Pathol. 2010;21:178-85.

63. Eng C, Mulligan LM, Smith DP, Healey CS, Frilling A, Raue F, Neumann HP, Pfragner R, Behmel A, Lorenzo MJ. Mutation of the RET protooncogene in sporadic medullary thyroid carcinoma. Genes Chromosomes Cancer. 1995;12:209-12.

64. Frich L, Glattre E, Akslen LA. Familial occurrence of nonmedullary thyroid cancer: A population-based study of 5673 first-degree relatives of thyroid cancer patients from Norway. Cancer Epidemiol Biomarkers Prev. 2001;10:113-7.

65. Feldman GL, Edmonds MW, Ainsworth PJ, Schuffenecker I, Lenoir GM, Saxe AW, Talpos GB, Roberson J, Petrucelli N, Jackson CE. Variable expressivity of familial medullary thyroid carcinoma (FMTC) due to a RET V804M (GTG-->ATG) mutation. Surgery. 2000;128:93-8.

66. Brown R, Colle E, Tashjian A. The syndrome of multiple mucoal neuromas and medullary thyroid carcinoma in childhood. J Pediatr. 1975; 86:77-83.

67. Akama H, Noshiro T, Kimura N, Shimizu K, Watanabe T, Shibukawa S, Nakai S, Miura W, Ito S, Miura Y. Multiple endocrine neoplasia type 2A with the identical somatic mutation in medullary thyroid carcinoma and pheochromocytoma without germline mutation at the corresponding site in the RET proto-oncogene [see comments]. Intern Med. 1999;38:145-9.

68. Carney J, Hales A. Alimentary tract manifestations of multiple endocrine neoplasia, type 2b. Mayo Clin Proc. 1977;52:543-8.

69. Carney J, Hales A, Pearse A, Perry H, Sizemore G. Abnormal cutaneous innervation in multiple endocrine neoplasia, type $2 \mathrm{~b}$. Ann Intern Med. 1981;94:262-3.

70. Carney J, Roth S, Heath H, Sizemore G, Hales A. The parathyroid glands in multiple endocrine neoplasia, type 2b. Am J Pathol. 1980;99:387-98.

71. Cirafici AM, Salvatore G, De Vita G, Carlomagno F, Dathan NA, Visconti R, Melillo RM, Fusco A, Santoro M. Only the substitution of methionine 918 with a threonine and not with other residues activates RET transforming potential. Endocrinology. 1997;138:1450-5. 
72. Jasim S, Ying AK, Waguespack SG, Rich TA, Grubbs EG, Jimenez C, Hu MI, Cote G, Habra MA. Multiple endocrine neoplasia type $2 \mathrm{~B}$ with a RET proto-oncogene A883F mutation displays a more indolent form of medullary thyroid carcinoma compared with a RET M918T mutation. Thyroid. 2011;21:189-92.

73. Roman S, Lin R, Sosa JA. Prognosis of medullary thyroid carcinoma: Demographic, clinical, and pathologic predictors of survival in 1252 cases. Cancer. 2006;107:2134-42.

74. Frank-Raue K, Rondot S, Raue F. Molecular genetics and phenomics of RET mutations: Impact on prognosis of MTC. Mol Cell Endocrinol. 2010;322:2-7.

75. Hedayati M, Zarif Yeganeh M, Sheikhol Eslami S, Rezghi Barez S, Hoghooghi Rad L, Azizi F. Predominant RET germline mutations in exons 10,11 , and 16 in Iranian patients with hereditary medullary thyroid carcinoma. J Thyroid Res. 2011;2011:264248.

76. Dourisboure RJ, Belli S, Domenichini E, Podesta EJ, Eng C, Solano AR. Penetrance and clinical manifestations of nonhotspot germline RET mutation, C630R, in a family with medullary thyroid carcinoma. Thyroid. 2005;15:668-71.

77. Schilling T, Burck J, Sinn HP, Clemens A, Otto HF, Hoppner W, Herfarth C, Ziegler R, Schwab M, Raue F. Prognostic value of codon 918 (ATG-->ACG) RET proto-oncogene mutations in sporadic medullary thyroid carcinoma. Int J Cancer. 2001;95:626.

78. Shirahama S, Ogura K, Takami H, Ito K, Tohsen T, Miyauchi A, Nakamura Y. Mutational analysis of the RET proto-oncogene in 71 Japanese patients with medullary thyroid carcinoma. J Hum Genet. 1998;43:101-6.

79. Allen SM, Bodenner D, Suen JY, Richter GT. Diagnostic and surgical dilemmas in hereditary medullary thyroid carcinoma. Laryngoscope. 2009;119:1303-11.

80. Niederle B. Screening for medullary carcinoma of the thyroid. Br J Surg. 2014;101:1625-6.

81. Learoyd DL, Robinson BG. Routine screening for germline RET mutations is recommended for all patients with medullary thyroid cancer. Nat Clin Pract Endocrinol Metab. 2009;5:6-7.

82. Wohllk N, Cote GJ, Evans DB, Goepfert H, Ordonez NG, Gagel RF. Application of genetic screening information to the management of medullary thyroid carcinoma and multiple endocrine neoplasia type 2. Endocrinol Metab Clin North Am. 1996;25:1-25

83. Chen H, Sippel RS, O'Dorisio MS, Vinik AI, Lloyd RV, Pacak K. The North American Neuroendocrine Tumor Society consensus guideline for the diagnosis and management of neuroendocrine tumors: Pheochromocytoma, paraganglioma, and medullary thyroid cancer. Pancreas. 2010;39:775-83.

84. Marsh DJ, Zheng Z, Arnold A, Andrew SD, Learoyd D, Frilling A, Komminoth P, Neumann HP, Ponder BA, Rollins BJ, Shapiro GI, Robinson BG, Mulligan LM, Eng C. Mutation analysis of glial cell line-derived neurotrophic factor, a ligand for an RET/ coreceptor complex, in multiple endocrine neoplasia type 2 and sporadic neuroendocrine tumors. J Clin Endocrinol Metab. 1997;82:3025-8.

85. Boccia LM, Green JS, Joyce C, Eng C, Taylor SA, Mulligan LM. Mutation of RET codon 768 is associated with the FMTC phenotype. Clin Genet. 1997;51:81-5.
86. Mulligan LM, Eng C, Healey CS, Clayton D, Kwok JB, Gardner E, Ponder MA, Frilling A, Jackson CE, Lehnert H. Specific mutations of the RET proto-oncogene are related to disease phenotype in MEN 2A and FMTC. Nat Genet. 1994;6:70-4.

87. Zedenius J, Larsson C, Bergholm U, Bovee J, Svensson A, Hallengren B, Grimelius L, Backdahl M, Weber G, Wallin G. Mutations of codon 918 in the RET proto-oncogene correlate to poor prognosis in sporadic medullary thyroid carcinomas. J Clin Endocrinol Metab. 1995;80:3088-90.

88. Jhiang SM, Fithian L, Weghorst CM, Clark OH, Falko JM, O'Dorisio TM, Mazzaferri EL. RET mutation screening in MEN2 patients and discovery of a novel mutation in a sporadic medullary thyroid carcinoma. Thyroid. 1996;6:115-21.

89. Marsh DJ, Learoyd DL, Andrew SD, Krishnan L, Pojer R, Richardson AL, Delbridge L, Eng C, Robinson BG. Somatic mutations in the RET proto-oncogene in sporadic medullary thyroid carcinoma. Clin Endocrinol. (Oxf) 1996;44:249-57.

90. Eng C, Mulligan LM. Mutations of the RET proto-oncogene in the multiple endocrine neoplasia type 2 syndromes, related sporadic tumours, and hirschsprung disease. Hum Mutat. 1997;9:97-109.

91. Fernandez RM, Robledo M, Antinolo G, Pecina A, Ruiz-Llorente S, Eng C, Borrego S. The RET IVS1-126G $>$ T variant is strongly associated with the development of sporadic medullary thyroid cancer. Thyroid. 2004;14:329-31.

92. Frank-Raue $\mathrm{K}$, Machens A, Leidig-Bruckner G, Rondot S, Haag C, Schulze E, Lorenz A, Kreissl MC, Dralle H, Raue F, Schmid KW. Prevalence and clinical spectrum of nonsecretory medullary thyroid carcinoma in a series of 839 patients with sporadic medullary thyroid carcinoma. Thyroid. 2013;23:294300.

93. Romei C, Cosci B, Renzini G, Bottici V, Molinaro E, Agate L, Passannanti P, Viola D, Biagini A, Basolo F, Ugolini C, Materazzi G, Pinchera A, Vitti P, Elisei R. RET genetic screening of sporadic medullary thyroid cancer (MTC) allows the preclinical diagnosis of unsuspected gene carriers and the identification of a relevant percentage of hidden familial MTC (FMTC). Clin Endocrinol. (Oxf) 2011;74:241-7.

94. Moura MM, Cavaco BM, Pinto AE, Leite V. High prevalence of RAS mutations in RET-negative sporadic medullary thyroid carcinomas. J Clin Endocrinol Metab. 2011; 96:E863-8.

95. Boichard A, Croux L, Al Ghuzlan A, Broutin S, Dupuy C, Leboulleux S, Schlumberger M, Bidart JM, Lacroix L. Somatic RAS mutations occur in a large proportion of sporadic RETnegative medullary thyroid carcinomas and extend to a previously unidentified exon. J Clin Endocrinol Metab. 2012;97:E2031-5.

96. Lyra J, Vinagre J, Batista R, Pinto V, Prazeres H, Rodrigues F, Eloy C, Sobrinho-Simoes M, Soares P. mTOR activation in medullary thyroid carcinoma with RAS mutation. Eur J Endocrinol. 2014;171:633-40.

97. Oczko-Wojciechowska M, Pfeifer A, Rusinek D, Pawlaczek A, Zebracka-Gala J, Kowalska M, Kowal M, Swierniak M, Krajewska J, Gawlik T, Chmielik E, Czarniecka A, Szpak-Ulczok S, Jarzab B. The prevalence of somatic RAS mutations in medullary thyroid cancer-a Polish population study. Endokrynol Pol. 2015;66:1215 . 
98. Evans DB, Burgess MA, Goepfert H, Gagel RF. Medullary thyroid carcinoma. Curr Ther Endocrinol Metab. 1997;6:127-32.

99. Sambade C, Baldaque-Faria A, Cardoso-Oliveira M, SobrinhoSimoes M. Follicular and papillary variants of medullary carcinoma of the thyroid. Pathol Res Prac. 1988;184:98-107.

100. Kawanishi N, Norimatsu Y, Ohsaki H, Yuminamochi T, Katoh R, Okusaki K, Sato Y, Kobayashi TK. Diagnosis of pseudopapillary variant of medullary thyroid carcinoma by fine-needle aspiration cytology. Diagn Cytopathol. 2014;42:823-6.

101. Albores-Saavedra J, Gorraez de la Mora T, de la Torre-Rendon F, Gould E. Mixed medullary-papillary carcinoma of the thyroid: A previously unrecognized variant of thyroid carcinoma. Hum Pathol. 1990;21:1151-5.

102. Shukla S, Awasthi NP, Husain N. Papillary variant of medullary carcinoma thyroid. Indian J Pathol Microbiol. 2014;57:151-2.

103. Hyrcza MD, Winer D, Mete O. Images in endocrine pathology: Papillary variant of medullary thyroid carcinoma with cystic change. Endocr Pathol. 2015;26:87-9.

104. Olinici CD, Vasiu R. Mixed folliculo-papillary and squamous cell variant of medullary thyroid carcinoma. Rom J Morphol Embryol. 1991;37:167-9.

105. Harach HR, Williams ED. Glandular (tubular and follicular) variants of medullary carcinoma of the thyroid. Histopathology. 1983;7:83-97.

106. Schroder S, Böcker W, Baisch H, Bürk CG, Arps H, Meiners I, Kastendieck H, Heitz PU, Klöppel G. Prognostic factors in medullary thyroid carcinoma. Survival in relation to age, sex, stage, histology, immunocytochemistry, and DNA content. Cancer. 1988;61:806-16.

107. Huss LJ, Mendelsohn G. Medullary carcinoma of the thyroid gland: An encapsulated variant resembling the hyalinizing trabecular (paraganglioma-like) adenoma of thyroid. Mod Pathol. 1990;3:581-5.

108. Mendhelsohn G, Oertel J. Encapsulated medullary thyroid carcinoma. Lab Invest. 1981;44:43a.

109. Kodama T, Okamoto T, Fujimoto Y, Obara T, Ito Y, Aiba M, Hirayama A. C-cell adenoma of the thyroid: A rare but distinct clinical entity. Surgery. 1988;104:997-1003.

110. Mendelsohn G, Baylin SB, Bigner SH, Wells SA Jr, Eggleston JC. Anaplastic variants of medullary thyroid carcinoma: A lightmicroscopic and immunohistochemical study. Am J Surg Pathol. 1980;4:333-41.

111. Kakudo K, Miyauchi A, Ogihara T, Takai SI, Kitamura H, Kosaki G, Kumahara Y. Medullary carcinoma of the thyroid. Giant cell type. Arch Pathol Lab Med. 1978;102:445-7.

112. Landon G, Ordonez NG. Clear cell variant of medullary carcinoma of the thyroid. Hum Pathol. 1985;16:844-7.

113. Dominguez-Malagon H, Delgado-Chavez R, Torres-Najera M, Gould E, Albores-Saavedra J. Oxyphil and squamous variants of medullary thyroid carcinoma. Cancer. 1989;63:1183-8.

114. Zaatari GS, Saigo PE, Huvos AG. Mucin production in medullary carcinoma of the thyroid. Arch Pathol Lab Med. 1983;107:70-4.

115. Singh ZN, Ray R, Kumar N, Aron M, Gupta SD. Medullary thyroid carcinoma with melanin production-a case report. Indian J Pathol Microbiol. 1999;42:159-63.
116. Mohamad I, Zainuddin N, Zawawi N, Naik VR. Melanocytic variant of medullary thyroid carcinoma in a previously treated papillary carcinoma patient. Ann Acad Med Singapore. 2011;40:300-1.

117. Kos M, Separovic V, Sarcevic B. Medullary carcinoma of the thyroid: Histomorphological, histochemical and immunohistochemical analysis of twenty cases. Acta Med Croatica. 1995;49:195-9.

118. DeLellis RA, Rule AH, Spiler I, Nathanson L, Tashjian AH Jr, Wolfe HJ. Calcitonin and carcinoembryonic antigen as tumor markers in medullary thyroid carcinoma. Am J Clin Pathol. 1978;70:587-94

119. Matsubayashi S, Yanaihara C, Ohkubo M, Fukata S, Hayashi Y, Tamai H, Nakagawa T, Miyauchi A, Kuma K, Abe K. Gastrinreleasing peptide immunoreactivity in medullary thyroid carcinoma. Cancer. 1984;53:2472-7.

120. Roth KA, Bensch KG, Hoffman AR. Characterization of opioid peptides in human thyroid medullary carcinoma. Cancer. 1987;59:1594-8.

121. Komminoth P, Roth J, Saremaslani P, Matias-Guiu X, Wolfe HJ, Heitz PU. Polysialic acid of the neural cell adhesion molecule in the human thyroid: A marker for medullary carcinoma and primary C-cell hyperplasia. An immunohistochemical study on 79 thyroid lesions. Am J Surg Pathol. 1994;18:399-411.

122. Yerly S, Triponez F, Meyer P, Kumar N, Bongiovanni M. Medullary thyroid carcinoma, small cell variant, as a diagnostic challenge on fine needle aspiration: A case report. Acta Cytol. 2010;54:911-7.

123. Ogawa H, Kino I, Arai T. Mixed medullary-follicular carcinoma of the thyroid. Immunohistochemical and electron microscopic studies. Acta Pathol Jpn. 1989;39:67-72.

124. Perrone T. Mixed medullary-follicular thyroid carcinoma. Am J Surg Pathol. 1986;10:362-3.

125. Sadow PM, Hunt JL. Mixed Medullary-follicular-derived carcinomas of the thyroid gland. Adv Anat Pathol. 2010;17:2825.

126. Abrosimov A. Histologic and immunohistochemical characterization of medullary thyroid carcinoma. Arkh Patol. 1996;58:43 8.

127. Papotti M, Volante M, Komminoth P, Sobrinho-Simoes M, Bussolati G. Thyroid carcinomas with mixed follicular and C-cell differentiation patterns. Semin Diagn Pathol. 2000;17:109-19.

128. Parker LN, Kollin J, Wu SY, Rypins EB, Juler GL. Carcinoma of the thyroid with a mixed medullary, papillary, follicular, and undifferentiated pattern. Arch Intern Med. 1985;145:1507-9.

129. Sobrinho-Simoes M. Mixed medullary and follicular carcinoma of the thyroid. Histopathology. 1993;23:287-9.

130. Collins BT, Cramer HM, Tabatowski K, Hearn S, Raminhos A, Lampe H. Fine needle aspiration of medullary carcinoma of the thyroid. Cytomorphology, immunocytochemistry and electron microscopy. Acta Cytol. 1995;39:920-30.

131. Oertel YC, Oertel JE. Diagnosis of malignant epithelial thyroid lesions: Fine needle aspiration and histopathologic correlation. Ann Diagn Pathol. 1998;2:377-400. 
132. Kumar PV, Hodjati H, Monabati A, Talei A. Medullary thyroid carcinoma. Rare cytologic findings. Acta Cytol. 2000;44:181-4.

133. Rossi ED, Raffaelli M, Mule A, Zannoni GF, Pontecorvi A, Santeusanio G, Minimo C, Fadda G. Relevance of immunocytochemistry on thin-layer cytology in thyroid lesions suspicious for medullary carcinoma: A case-control study. Appl Immunohistochem Mol Morphol. 2008;16:548-53.

134. Zhang B, Jiang YX, Liu JB, Yang M, Dai Q, Zhu QL, Gao P. Utility of contrast-enhanced ultrasound for evaluation of thyroid nodules. Thyroid. 2010;20:51-7.

135. Cai S, Liu H, Li WB, Ouyang YS, Zhang B, Li P, Wang XL, Zhang XY, Li JC, Jiang YX. Ultrasonographic features of medullary thyroid carcinoma and their diagnostic values. Chin Med J. (Engl) 2010;123:3074-8.

136. Kini SR, Miller JM, Hamburger JI, Smith MJ. Cytopathologic features of medullary carcinoma of the thyroid. Arch Pathol Lab Med. 1984;108:156-9.

137. Galimberti A, Vitri P, De Pasquale L, Gobbi G, Bastagli A. Utility of fine needle aspiration and frozen section in the diagnosis of uncommon thyroid malignancies. J Exp Clin Cancer Res. 1997; 16:425-6.

138. Us-Krasovec M, Auersperg M, Bergant D, Golouh R, KlobovesPrevodnik V. Medullary carcinoma of the thyroid glad: Diagnostic cytopathological characteristics. Pathologica. 1998;90:5-13.

139. Akbulut M, Zekioglu O, Kapkac M, Ozdemir N. Fine needle aspiration cytologic features of medullary carcinoma of the breast: A study of 20 cases with histologic correlation. Acta Cytol. 2009;53:165-73.

140. Tranchida P, Estigarribia J, Sethi S, Giorgadze T. Cytologic diagnosis of recurrent medullary thyroid carcinoma with oncocytic change twenty-one years post-thyroidectomy: Case report and review of the literature. Diagn Cytopathol. 2011;39:641-6.

141. Trimboli P, Treglia G, Guidobaldi L, Romanelli F, Nigri G, Valabrega S, Sadeghi R, Crescenzi A, Faquin WC, Bongiovanni $\mathrm{M}$, Giovanella L. Detection rate of FNA cytology in medullary thyroid carcinoma: A meta-analysis. Clin Endocrinol. (Oxf) 2015;82:280-5.

142. Forrest CH, Frost FA, de Boer WB, Spagnolo DV, Whitaker D, Sterrett BF. Medullary carcinoma of the thyroid: Accuracy of diagnosis of fine-needle aspiration cytology. Cancer. 1998;84:295-302.

143. Das DK, Mallik MK, George SS, Sheikh ZA, Pathan SK, Haji BE, Al-Quaddomi SA, Mirza K, Ajrawi MT, Amir T, Dey P, Francis IM. Secretory activity in medullary thyroid carcinoma: A cytomorphological and immunocytochemical study. Diagn Cytopathol. 2007;35:329-37.

144. Papaparaskeva K, Nagel H, Droese M. Cytologic diagnosis of medullary carcinoma of the thyroid gland. Diagn Cytopathol. 2000;22:351-8.

145. Pacini F, Fontanelli M, Fugazzola L, Elisei R, Romei C, Di Coscio G, Miccoli P, Pinchera A. Routine measurement of serum calcitonin in nodular thyroid diseases allows the preoperative diagnosis of unsuspected sporadic medullary thyroid carcinoma [see comments]. J Clin Endocrinol Metab. 1994;78:826-9.
146. Siqueira D, Rocha AP, Punales MK, Maia AL. Identification of occult metastases of medullary thyroid carcinoma by calcitonin measurement in washout fluid from fine needle aspiration of cervical lymph node. Arq Bras Endocrinol Metabol. 2009;53:479 81.

147. Trimboli P, Rossi F, Baldelli R, Laurenti O, Nigri G, Ventura C, Appetecchia M, Attanasio D, Romanelli F, Guidobaldi L, Guarino M, Crescenzi A, Valabrega S. Measuring calcitonin in washout of the needle in patients undergoing fine needle aspiration with suspicious medullary thyroid cancer. Diagn Cytopathol. 2012;40:394-8.

148. DeLellis RA, Nunnemacher G, Wolfe HJ. C-cell hyperplasia. An ultrastructural analysis. Lab Invest. 1977;36:237-48.

149. Gibson W, Peng T, Croker B. C-cell nodules in adult human thyroid: A common autopsy finding. Am J Clin Pathol. 1980;73:347-51.

150. Wolfe HJ, Delellis RA. Familial medullary thyroid carcinoma and C cell hyperplasia. Clin Endocrinol Metab. 1981;10:351-65.

151. Carney J, Sizemore G, Hales A. Multiple endocrine neoplasia, type 2b. Pathobiol Annu. 1978;8:105-53.

152. Perry A, Molberg K, Albores-Saavedra J. Physiologic versus neoplastic C-cell hyperplasia of the thyroid: Separation of distinct histologic and biologic entities. Cancer. 1996;77:750-6.

153. Guyetant S, Wion-Barbot N, Rousselet MC, Franc B, Bigorgne JC, Saint-Andre JP. C-cell hyperplasia associated with chronic lymphocytic thyroiditis: A retrospective quantitative study of 112 cases. Hum Pathol. 1994;25:514-21.

154. Leboulleux S, Baudin E, Travagli JP, Schlumberger M. Medullary thyroid carcinoma. Clin Endocrinol. (Oxf) 2004;61:299-310.

155. Albores-Saavedra J, Monforte H, Nadji M, Morales AR. C-cell hyperplasia in thyroid tissues adjacent to follicular cell tumors. Hum Pathol. 1988;19:795-9.

156. Williams ED, Ponder BJ, Craig RK. Immunohistochemical study of calcitonin gene-related peptide in human medullary carcinoma and C cell hyperplasia. Clin Endocrinol. (Oxf) 1987;27:107-14

157. Kaserer K, Scheuba C, Neuhold N, Weinhausel A, Haas OA, Vierhapper H, Niederle B. Sporadic versus familial medullary thyroid microcarcinoma: A histopathologic study of 50 consecutive patients. Am J Surg Pathol. 2001;25:1245-51.

158. Kaserer K, Scheuba C, Neuhold N, Weinhausel A, Vierhapper H, Haas OA, Niederle B. C-cell hyperplasia and medullary thyroid carcinoma in patients routinely screened for serum calcitonin. Am J Surg Pathol. 1998;22:722-8.

159. Krueger JE, Maitra A, Albores-Saavedra J. Inherited medullary microcarcinoma of the thyroid: A study of 11 cases. Am J Surg Pathol. 2000;24:853-8

160. Baloch ZW, LiVolsi VA. Microcarcinoma of the thyroid. Adv Anat Pathol. 2006;13:69-75

161. Crespel A, De Boisvilliers F, Gros L, Kervran A. Effects of glucagon and glucagon-like peptide-1-(7-36) amide on C cells from rat thyroid and medullary thyroid carcinoma CA-77 cell line. Endocrinology. 1996;137:3674-80.

162. Nauck MA, Friedrich N. Do GLP-1-based therapies increase cancer risk? Diabetes Care. 2013;36 Suppl 2:S245-52. 
163. Albores-Saavedra JA, Krueger JE. C-cell hyperplasia and medullary thyroid microcarcinoma. Endocr Pathol. 2001;12:36577.

164. Kazaure HS, Roman SA, Sosa JA. Medullary thyroid microcarcinoma: A population-level analysis of 310 patients. Cancer. 2012;118:620-7.

165. Guyetant S, Dupre F, Bigorgne JC, Franc B, Dutrieux-Berger N, Lecomte-Houcke M, Patey M, Caillou B, Viennet G, Guerin O, Saint-Andre JP. Medullary thyroid microcarcinoma: A clinicopathologic retrospective study of 38 patients with no prior familial disease. Hum Pathol. 1999;30:957-63.

166. Ravitch MM. Diagnosis and prognosis of medullary carcinoma of the thyroid. Med Times. 1974;102:131-2.

167. Randolph GW, Maniar D. Medullary carcinoma of the thyroid. Cancer Control. 2000;7:253-61.

168. Zhang ZX, Li ZJ, Tang PZ, Xu ZG, Zhang ZM, An CM. Surgical treatment and prognosis analysis on medullary thyroid carcinoma. Zhonghua Er Bi Yan Hou Tou Jing Wai Ke Za Zhi. 2011;46:209-13.

169. Rendl G, Manzl M, Hitzl W, Sungler P, Pirich C. Long-term prognosis of medullary thyroid carcinoma. Clin Endocrinol. (Oxf) 2008;69:497-505.

170. Gilliland FD, Hunt WC, Morris DM, Key CR. Prognostic factors for thyroid carcinoma. A population-based study of 15, 698 cases from the Surveillance, Epidemiology and End Results (SEER) program 1973-1991. Cancer. 1997;79:564-73.

171. Takami H, Niimi M, Ikeda Y. Prognosis of a family with familial medullary thyroid carcinoma. J Exp Clin Cancer Res. 1999;18:223-4.

172. Samaan NA, Schultz PN, Hickey RC. Medullary thyroid carcinoma: Prognosis of familial versus nonfamilial disease and the role of radiotherapy. Horm Metab Res Suppl. 1989;21:21-5.

173. Schreinemakers JM, Vriens MR, Valk GD, de Groot JW, Plukker JT, Bax K, Hamming JF, van der Luijt RB, Aronson DC, Borel Rinkes IH. Factors predicting outcome of total thyroidectomy in young patients with multiple endocrine neoplasia type 2: A nationwide long-term follow-up study. World J Surg. 2010;34:852-60.

174. Melvin K, Tashjian A, Miller H. Studies in familial medullary thyroid carcinoma. Recent Prog Horm Res. 1972;28:399-470.

175. Schroder S, Bocker W, Baisch H, Burk CG, Arps H, Meiners I, Kastendieck H, Heitz PU, Kloppel G. Prognostic factors in medullary thyroid carcinomas. Survival in relation to age, sex, stage, histology, immunocytochemistry, and DNA content. Cancer. 1988; 61:806-16.

176. Chi DD, Toshima K, Donis-Keller H, Wells SA, Jr. Predictive testing for multiple endocrine neoplasia type 2A (MEN 2A) based on the detection of mutations in the RET protooncogene. Surgery. 1994;116:124-32; discussion 132-23.

177. Brandi ML, Gagel RF, Angeli A, Bilezikian JP, Beck-Peccoz P, Bordi C, Conte-Devolx B, Falchetti A, Gheri RG, Libroia A, Lips CJ, Lombardi G, Mannelli M, Pacini F, Ponder BA, Raue F, Skogseid B, Tamburrano G, Thakker RV, Thompson NW, Tomassetti P, Tonelli F, Wells SA Jr, Marx SJ. Guidelines for diagnosis and therapy of MEN type 1 and type 2. J Clin Endocrinol Metab. 2001;86:5658-71.
178. American Thyroid Association Guidelines Task F, Kloos RT, Eng C, Evans DB, Francis GL, Gagel RF, Gharib H, Moley JF, Pacini F, Ringel MD, Schlumberger M, Wells SA, Jr. Medullary thyroid cancer: management guidelines of the American Thyroid Association. Thyroid. 2009; 19:565-612.

179. Fleming JB, Lee JE, Bouvet M, Schultz PN, Sherman SI, Sellin RV, Friend KE, Burgess MA, Cote GJ, Gagel RF, Evans DB. Surgical strategy for the treatment of medullary thyroid carcinoma. Ann Surg. 1999;230:697-707.

180. Carli AF, Mariani F, Di Cosmo L, Giuli R, Neri A. Familial medullary thyroid carcinoma (FMTC). Study of one family (treatment criteria). Eur J Surg Oncol. 2001;27:162-4.

181. Dionigi G, Tanda ML, Piantanida E. Medullary thyroid carcinoma: Surgical treatment advances. Curr Opin Otolaryngol Head Neck Surg. 2008; 16:158-62.

182. Shikare S, Bashir K, Menon PS, Bapat RD, Tilve GH. Detection of medullary carcinoma of thyroid, with liver metastasis, using 99mTc DMSA(V) scintigraphy. J Postgrad Med. 1995;41:12-3.

183. Waters KM, Ali SZ, Erozan YS, Olson MT. Smoldering medullary thyroid carcinoma liver metastasis 37 years after resection of an organ-confined tumor. Diagn Cytopathol 2015; 43:45-8.

184. Yildiz I, Sen F, Tuncer S, Kilic L, Basaran M, Bavbek S. Optic disc and choroidal metastasis from sporadic medullary thyroid carcinoma: Case report and review of the literature. Onkologie. $2011 ; 34: 630-3$.

185. Karga H, Giagourta I, Papaioannou G, Doumouchtsis K, Polymeris A, Thanou S, Papamichael K, Zerva C. Changes in risk factors and Tumor Node Metastasis stage of sporadic medullary thyroid carcinoma over 41 years, before and after the routine measurements of serum calcitonin. Metabolism. 2011;60:604-8.

186. Imperiale A, Greget M, Chabrier G, Keomany J, Rust E, Detour J, Pessaux P, Goichot B. Solitary hepatic metastasis from medullary thyroid carcinoma mimicking atypical hemangioma: Insights from multimodality diagnostic approach by MRI, F-18 FDG and F-18 FDOPA PET/CT. Clin Nucl Med. 2010;35:434-7.

187. Bobinski M, Greco CM, Schrot RJ. Giant intracranial medullary thyroid carcinoma metastasis presenting as apoplexy. Skull Base. 2009;19:359-62.

188. Basu S, Shet T. Unilateral solitary breast metastasis from medullary carcinoma of thyroid detected by FDG-PET. Clin Nucl Med. 2010;35:512-3.

189. Abraham D, Jackson N, Gundara JS, Zhao J, Gill AJ, Delbridge L, Robinson BG, Sidhu SB. MicroRNA profiling of sporadic and hereditary medullary thyroid cancer identifies predictors of nodal metastasis, prognosis, and potential therapeutic targets. Clin Cancer Res. 2011; 17:4772-81.

190. Fagin JA, Tuttle RM, Pfister DG. Harvesting the low-hanging fruit: Kinase inhibitors for therapy of advanced medullary and nonmedullary thyroid cancer. J Clin Endocrinol Metab. 2010; 95:2621-4.

191. Sherman SI. Targeted therapy of thyroid cancer. Biochem Pharmacol. 2010; 80:592-601.

192. Solomon B, Rischin D. Progress in molecular targeted therapy for thyroid cancer: Vandetanib in medullary thyroid cancer. J Clin Oncol. 2012;30:119-21. 
193. Koch L. Pharmacotherapy: Vandetanib-a new therapeutic option in advanced medullary thyroid cancer. Nat Rev Endocrinol. 2011;8:1.

194. Torino F, Paragliola RM, Barnabei A, Corsello SM. Medullary thyroid cancer: A promising model for targeted therapy. Curr Mol Med. 2010;10:608-25.

195. Kraeber-Bodere F, Bodet-Milin C, Niaudet C, Sai-Maurel C, Moreau A, Faivre-Chauvet A, Thomare P, Deleris G, EstieuGionnet K, Bikfalvi A, Barbet J, Paris F. Comparative toxicity and efficacy of combined radioimmunotherapy and antiangiogenic therapy in carcinoembryonic antigen-expressing medullary thyroid cancer xenograft. J Nucl Med. 2010;51:624-31.

196. Wells SA, Jr., Gosnell JE, Gagel RF, Moley J, Pfister D, Sosa JA, Skinner M, Krebs A, Vasselli J, Schlumberger M. Vandetanib for the treatment of patients with locally advanced or metastatic hereditary medullary thyroid cancer. J Clin Oncol. 2010;28:76772.

197. Wells SA, Jr., Robinson BG, Gagel RF, Dralle H, Fagin JA, Santoro M, Baudin E, Elisei R, Jarzab B, Vasselli JR, Read J, Langmuir P, Ryan AJ, Schlumberger MJ. Vandetanib in patients with locally advanced or metastatic medullary thyroid cancer: A randomized, double-blind phase III trial. J Clin Oncol. 2012;30:134-41.

198. Elisei R, Schlumberger MJ, Muller SP, Schoffski P, Brose MS, Shah MH, Licitra L, Jarzab B, Medvedev V, Kreissl MC, Niederle B, Cohen EE, Wirth LJ, Ali H, Hessel C, Yaron Y, Ball D, Nelkin B, Sherman SI. Cabozantinib in progressive medullary thyroid cancer. J Clin Oncol. 2013;31:3639-46.
199. Houvras Y, Wirth LJ. Cabozantinib in medullary thyroid carcinoma: Time to focus the spotlight on this rare disease. J Clin Oncol. 2011; 29:2616-8.

200. Kurzrock R, Sherman SI, Ball DW, Forastiere AA, Cohen RB, Mehra R, Pfister DG, Cohen EE, Janisch L, Nauling F, Hong DS, Ng CS, Ye L, Gagel RF, Frye J, Muller T, Ratain MJ, Salgia R. Activity of XL184 (Cabozantinib), an oral tyrosine kinase inhibitor, in patients with medullary thyroid cancer. J Clin Oncol. 2011; 29:2660-6.

201. Durante C, Russo D, Verrienti A, Filetti S. XL184 (cabozantinib) for medullary thyroid carcinoma. Expert Opin Investig Drugs. 2011; 20:407-13.

202. Sherman SI, Brierley JD, Sperling M, Ain KB, Bigos ST, Cooper DS, Haugen BR, Ho M, Klein I, Ladenson PW, Robbins J, Ross DS, Specker B, Taylor T, Maxon HR, 3rd. Prospective multicenter study of thyroid carcinoma treatment: Initial analysis of staging and outcome. National Thyroid Cancer Treatment Cooperative Study Registry Group. Cancer. 1998; 83:1012-21. 